Bu makaleye atıfta bulunmak için/To cite this article:

KÖSE, H. SALAMOV, N. (2021). TV Tartışma Programlarında Çarpıtma Unsurları: II. Karabağ Savaşı (Ermenistan-Azerbaycan Çatışması) Örneği. Atatürk Üniversitesi Sosyal Bilimler Enstitüsü Dergisi, 25 (Özel Sayl), 128-152.

\title{
TV Tartışma Programlarında Çarpıtma Unsurları: II. Karabă̆ Savaşı (Ermenistan-Azerbaycan Çatışması) Örneği
}

\author{
Hüseyin KÖSE ${ }^{(*)}$ \\ Nurlan SALAMOV ${ }^{(* *)}$
}

Öz: 2020 yllında dünyanın siyasal gündemine oturan, küresel siyaseti, uluslararası ilişkileri ve medyayı etkileyen II. Karabă̆ Savaşı, uzun zaman araştırmalara konu olacă̆a benzemektedir. Bu tarihsel olayl, yalnızca bir askeri operasyon olarak değerlendirmemek gerekir. Savaşın, bölgede politik dengeleri değiştirmesinden iletişimsel süreçleri ve söylem düzenlerini etkilemesine kadar farklılaşan boyutları bulunmaktadır. Bu çalışmada, II. Karabağ Savaşı nın medyadaki söylem yansımalarına dair bir araştırma yapmak amaçlanmıştır. Bu bağlamda Habertürk ve CNN Türk TV kanallarında yayımlanan 4 tartışma programından birer program örneği çözümlenmiştir. Çalışmada retorik kavramı-tartışma programları iliş̧isi odağında, II. Karabağ Savaşı içerikli program örnekleri amaçsal örnekleme yöntemiyle, içerik çözümlemesi ve retorik çözümleme yöntemleri kullanılarak değerlendirilmiştir. Sonuç olarak, Türkiye elektronik medyasının, olgusal gerçeğe sadık kalıyormuş gibi görünerek, aslında ciddi editöryal içeriği konuşmacıların retorik çarpıtmalarla takdim etmelerini dikkate almayıp, reyting kaygılarıyla biçimlenmiş "politainement" türü bir tartışma kültürü üretmeyi tercih ettiği gözlenmiştir.

Anahtar Kelimeler: Çarpıtma, retorik, tv tartışma programları, II. Karabağ Savaşı.

\section{Distortion Elements in TV Discussion Programs: Second Nagorno- Karabakh War (Armenia-Azerbaijan Conflict) Example}

Abstract: It seems that the Second Nagorno-Karabakh War, which was on the world's political agenda in 2020 and affected global politics, international relations and the media, will be the subject of research for a long time. This historical event should not be evaluated only as a military operation. War has varying dimensions from changing the political balances in the region to affecting communicative processes and discourse patterns. This study aims to research the reflections of the Second Nagorno-Karabakh War on the discourse in the media. In this regard, one program example from 4 discussion programs broadcasted on Habertürk and CNN Türk TV channels was analyzed. In the study, the program samples including the Second NagornoKarabakh War were evaluated using purposive sampling method and content analysis and rhetorical analysis methods based on relationship between the concept of rhetoric and discussion programs. In conclusion, it was observed that Turkish electronic media, pretending to stay true to the factual truth, actually ignores the serious editorial content presented by the speakers with rhetorical distortions, and prefers to produce a "politainement" type of discussion culture shaped by rating concerns.

Keywords: Distortion, rhetoric, tv discussion programs, Second Nagorno-Karabakh War.

\footnotetext{
${ }^{*}$ Prof. Dr., Atatürk Üniversitesi İletişim Fakültesi Gazetecilik Bölümü (e-posta: huseyink180@yahoo.com) (D) ORCID ID. https://orcid.org/0000-0001-5697-9009

${ }^{* *}$ Doktora Öğrencisi, Atatürk Üniversitesi Sosyal Bilimler Enstitüsü Gazetecilik Ana Bilim Dalı, (e-posta: nurlan.salamov19@ogr.atauni.edu.tr) (D) ORCID ID. https://orcid.org/0000-0002-96638871

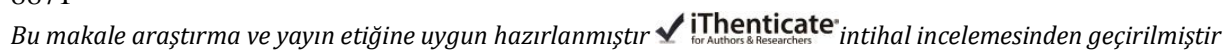


Makale Geliş Tarihi: 04.06.2021

Makale Kabul Tarihi: 20.09.2021

DOI: 10.53487/ataunisosbil.948184

\section{Giriş}

İçinde yaşadığımız modern toplumsal dünya ve onun tarihsel gelişim sürecinde ortaya çıkmış her olgunun kökeni aslında antik dönemde üretilmiş bakış açıları ve kanaatler aracıllğıyla yorumlanabilir. Yeni olan her fenomen ve ona ait düşünce, büyük ölçüde eskinin üzerinde çalışılmış ve şu veya bu şekilde ondan referansla geliştirilmiş versiyonudur denebilir. Kadim zamanlardan beri mevcut prensipler, fikirler, kanaat ve yaklaşımlar, söylem biçimleri, vb. hepsi günümüzde daha modern bir formda karşımıza çıkmış olgu ve görüngülerdir. Bu çalışmanın analiz konusunu oluşturan toplumsal olay ve ona ilişkin üretilen yorumlamalar; daha somut bir deyişle, konuşmalardaki çarpıtma unsurları ve bunun medya aracılı̆̆ ile gerçekleştirilmesi, antik dönemin retorik kavramı odağında analiz edilmiştir. Retorik, zaman geçtikçe bir bilim veya sanat biçimini alarak birçok alana dek yayılmış, tarihsel süreçte ortaya çıkan yeni iletişim biçimlerine de yenik düşmemiştir. Tam aksine, bugün deneyimlemekte olduğumuz dijital medya evreninde, dijital kültürü oluşturan değer, olgu, süreç ve araçlarda bile retoriğin temel unsurlarına rastlanmaktadır. Medya kavramı da, tıpkı retorik kavramı gibi, kökleri oldukça eskilere dayanan bir tarihçeye sahiptir. Bilgilendirme amaçlı taş levhaların milattan önce Eski Roma'da kullanıldı̆ı günden bu yana medyanın tarihi aynı zamanda ikna etme yöntemlerinin de tarihidir. Dahası, bugün de medya ve retorik kavramları birbirinden ayrı düşünülebilecek alanlar değildir. Dolayısıyla çalışmanın amacını, Antik Çağ'da, hatta tarihsel olarak çok daha öncesinde Sümer Uygarlığı'nda yaygın bir kullanım alanı olan retoriğin, medyanın bir ikna aracı olarak sahip olduğu işlevle benzer işlevlere sahip olduğu varsayımının sınanması oluşturmaktadır. Çalışmanın analiz bölümünde, ilgili tartışma programı bölümleri; medya seçkinleri, kanaat önderleri, uzmanlar, vd. kişilerin davranışları, söylem icraları ve ikna etme/hile/çarpıtma yöntemleri temelinde, modern retorik kavramına özgü ilkeler çerçevesinde yorumlanmıştır. Bu bağlamda, Habertürk TV'den "Açılk ve Net" ve "Gerçek Fikri Ne?" programlarının 28 Eylül-3 Ekim 2020 tarihleri arasındaki dört bölümü ile; CNN Türk TV'den "CNN Türk Masası" ve "Tarafsız Bölge" programlarının 3-19 Ekim 2020 tarihleri arasında yayımlanmış dört bölümü olmak üzere, toplam sekiz program örneği analiz edilmiştir.

\section{II. Çalışmanın Amacı ve Önemi}

Araştırmamızın amacı, milattan öncesine kadar dayanan bir kavram olarak retoriğin ve en önemlisi de, onun bir alt bileşenini oluşturan çarpıtmanın, günümüzde de birçok alanda ve farklı formlarda kullanıldığı, özelde ise televizyon tartışma programlarında nasıl karşımıza çıktığı ile ilgili bir bakış açısı oluşturmaktır. Bu bağlamda, çalışmada televizyon tartışma programlarındaki konuşmacıların söylemlerinde aleni ve zımni olarak başvurdukları çarpıtma unsurlarının tartışma içeriğinde ne tür anlam sapmaları yarattığı sorusu irdelenmeye çalışılmıştır. Çalışma öncesinde, ilgili anahtar kelimeler girilerek, tez.yok.gov.tr, dergipark.org.tr ve scolar.google.com adreslerinin veri tabanlarında ayrıntılı bir literatür taraması gerçekleştirilmiştir. Yapılan tarama sonucunda; Arap ülkelerinin II. Karabağ Savaşı'nda sınırların değişimi ve güvenlik 
TV Tartışma Programlarında Çarpıtma Unsurları: II. Karabağ Savașı (ErmenistanAzerbaycan Çatışması) Örneği

sorunlarına yönelik tutumları, II. Karabağ Savaşı sonrası bölgede değişen roller, savaşın askeri açıdan analizi ve Türkiye, Azerbaycan ve Ermenistan'a yönelik sosyal ve ekonomik etkileri, vb. konu ve içeriklere sahip çok sayıda bilimsel yayına ulaşılmıştır. $\mathrm{Bu}$ yayınlar arasında yalnızca birisinin savaşı özel olarak medya ve habercilik bağlamında tartışmaya açtığı görülmüştür. Söz konusu çalışma, özetle, savaşı Türkiye'de yayın yapan DW Türkçe, BBC Türkçe ve Sputnik Türkiye gibi yabancı haber siteleri ve habercilik politikalarının tarafsızlığı açısından değerlendirmektedir. Yine yapılan taramada, YÖK Ulusal Tez Veri Sistemi'nde II. Karabağ Savaşı konusunda yapılmış lisansüstü bir tez örneğine rastlanmamıştır. Bu veriler ışığında denebilir ki, "TV Tartı̧̧a Programlarında Çarpıtma Unsurları: II. Karabağ Savaşı (Ermenistan-Azerbaycan Çatışması) Örneğì" başlıklı makale çalışması, konuyu gerek haber-söylem-ideoloji ilişkisi bağlamında dikkate alan analiz çerçevesi, gerekse televizyon tartışmalarında tartışmacıların sıklıkla başvurdukları tartışma hileleri ve dilsel çarpıtma unsurlarına odaklanması bakımından önemlidir. Bir başka deyişle, çalışmanın özgün değeri kuşkusuz olası bazı eksikliklerine rağmen-, II. Karabă̆ Savaşı'na ilişkin üretilen medya içeriğinin retorik çarpıtma unsurlarıyla ilişkisinin TV tartışma programları açısından ilk kez değerlendirilmiş olmasıdır.

\section{III. Çalışmanın Yöntemi}

Çalışma materyali, retorik analiz ve içerik çözümlemesi yöntemlerinin her ikisinin birlikte kullanılması ile çözümlenmiştir. Görsel ve işitsel ögeler ile yazılı dilin ikna edici bir bağlam içerisinde yeniden kurgulanması şeklinde ele alabileceğimiz retoriğe dayalı analizin esasen beş temel üzerinde kurulduğu söylenebilir: Vaat ve vaat desteği, mesajın formatı, tarzı, tonu ve yapım biçimi, kullanılan görsel-işitsel ve yazılı retorik enstrümanlar medya ve akılda kalıcılık için iyi bir kapanış ve tekrar (Sever, 2015: 321324). Birimlerin çözümlenmesinde kullanılmış olan içerik analizi, yazılı, görsel ve işitsel türlerdeki kayıtlı metinlere uygulanabilen bir yöntem olarak, kavram ve temaların düşük maliyetle incelenme, veri sağlamada kolaylık, geniş metinleri kolay işlenebilen sayısal verilere dönüştürebilme, vb. açılardan avantajlıdır (Berger, 1998: 26). İkinci olarak, retorik çözümleme yöntemi ise, temelinde ikna unsurunun bulunduğu konuşmalar veya yazılı metinlerin çözümlenmesinde kullanılan bir araştırma yöntemidir. Retorik analizin uygulanması, kesin hatlarla belirlenmiş bir modele sahip olmayıp farklı kategoriler ve basamaklarla gerçekleştirilebilir (Bıçakçı, 2012: 346). Bu çözümleme yönteminde, genellikle Aristoteles'in retoriğe dair bilgiler ve sinıflandırmaları referans alınarak dört basamaklı bir sistem uygulanmaktadır. Bunlar: Kimin ne için ikna etmeye çalıştığını ortaya koyarak konuşma veya yazılı metindeki retoriksel durumun ifade edilmesi; Aristoteles'in belirlediği üzere, retoriğin hangi türünün kullanıldığının saptanması; retoriğin aşamaları olarak kabul edilen buluş, düzenleme, tarz, sunuş ve bellek kanonlarının belirlenmesi ve analizin yeniden değerlendirilmesi ve sağlamlaştırılması (Leach, 2000: 225). Ayrıca retorik çözümleme, televizyon haberlerinde haber içerikleri ve haber sunuş biçimlerinin analizinde de sıklıkla başvurulan bir yöntemdir. Bu anlamda retoriği görsel-işitsel öğeler ile yazılı dilin ikna edici bir bağlamı içinde yeniden kurgulanması olarak da tanımlayabiliriz. Retoriği bu şekilde tanımladığımız zaman retorik analizinin amacının iletişimcilerin açık ya da çoğu zaman saklı anlam yüklemelerinin görsel-işitsel ve yazıll-sözlü iletişim biçimlerinde aranması ve ortaya 
konması olarak tanımlamak gerekir. $\mathrm{Bu}$ açıdan, tartı̧̧ma programları uzmanlarının konuşmalarındaki sözsüz iletişim ögeleri ve herhangi bir soruya yanıt verdikleri zaman sergilemiş oldukları duraksama, kaş çatma, öfkelenme, araya girme, lafı dolandırma, sunucunun sözünü kesme, istihza etme, gülme vb. beden dili tepkileri de çözümlemeye tabi tutulmuştur.

Çalışma verileri, çözümlemesi yapılan materyalin internet üzerindeki video kayıtlarının izlenmesiyle değil, II. Karabağ Savaşı'nın halen devam ettiği günlerde yayımlanan tartışma program içeriklerinin ekrandan canlı olarak izlenmesi yoluyla elde edilmiştir. İzleme yoluyla toplanan verilerin içerik analizi, Aristoteles'çi retorik anlayışında özellikle yazılı ve sözlü tartışmalarda sıkça başvurulan ve Aristo'nun Retorik adlı eserinin "Üçüncü Kitap"ında değinerek kısaca "kanıtlama ve inandırma yolları" (2014: 143-160) adını verdiği yaygın tartışma hileleri ve dilsel çarpıtma unsurları dikkate alınarak gerçekleştirilmiştir. Ancak burada Aristo'nun Retorik adlı eserinde yazilanlardan hareketle, Arthur Schopenhauer tarafindan belirlenen toplam 38 kategorinin tümü değil, yalnızca konumuzla ilişkili olarak, 'politik konuşma' biçimlerinde başvurulan tartışma hileleri ve dilsel çarpıtma unsurları dikkate alınmışıtır. Dolayısıyla çalışmada toplam 14 çözümleme kategorisi belirlenmiş olup, bunlar aşă̆ıdaki gibidir:

1) Muhatabın iddiasını bağlamsız sınırların ötesine dek genişletme,

2) Yanlış ve kasıtlı önermeler kullanma,

3) Muhatabını kızdırma,

4) İddiayı daha da güçlü kılmak adına özdeyiş kullanma,

5) Zorluk çıkarma,

6) Tribünlere oynama,

7) Anlamazdan gelme,

8) Mantıksal benzerlikler kurma,

9) Daha önceki hataları kendi savunmasının temeli yapma,

10) Bir olayın asıl nedeni olmayan şeyi o olayın gerçek nedeni gibi sunma,

11) Rastlantısal olanı temel olarak alma,

12) Muhatabın önermesini, ondan yanlış bir çıkarımda bulunarak değersizleştirme,

13) Herhangi bir zaman ya da koşuldan söz etmeme,

14) Sonuçtan kanıt çıkarma, vb. (Schopenhauer, 2012a: 85-120).

Retorik analiz yönteminden ise, yukarıda da belirtildiği üzere, çalışmanın görselişitsel öğeler ile yazılı dilin ikna edici bir bağlamı içinde yeniden kurgulanması bağlamında yararlanılmıştır. Söz konusu bağlam, çalışmada konuşmacıların başvurdukları kimi tanımlamalar, kanıtlayıcı malzeme sunumu, mecaz kullanımı, imalı anlatım, vb. dil kullanımlarıdır. 
TV Tartışma Programlarında Çarpıtma Unsurları: II. Karabağ Savașı (ErmenistanAzerbaycan Çatışması) Örneği

\section{IV. Çalışmanın Evreni ve Örneklemi}

Çalışmanın evrenini, II. Karabağ Savaşı'nın devam ettiği tarihlerde Türkiye ulusal televizyon kanallarının akşam yayın kuşaklarında yayımlanan tartışma programları oluşturmaktadır. Bu bağlamda çalışmanın evrenini; Haber Türk TV'de yayımlanan 8 (HT 360, Teke Tek, Açık ve Net, Nedir Ne Değildir?, Enine Boyuna, Olaylar ve Görüşler, Habertürk Gündem, Eren Eğilmez ile Gerçek Fikri Ne?); CNN Türk TV'de yayımlanan 5 (Akıl Çemberi, Gece Görüşü, Ahmet Hakan'la Tarafsız Bölge, Gündem, Semiha Şahin'le CNN Türk Masası); A Haber'de yer alan 7 (Canan Barlas'la Gündem, Yüz Yüze Siyaset, Her Yöne 80 Dakika, Memleket Meselesi, Toplumsal Hafiza, Yaz-Boz, Söz Teması); NTV'de 2 (Yorum Farkı, Ahmed Arpad İle Siyasi İşler); Halk TV'de 3 (Perdenin Önü Arkası, Özlem Gürses İle Kayda Geçsin, Gökmen Karadağ İle Açıça); Haber Global'de 3 (Saynur Tezel Ile Kaylt Altında, Senem Toluay Ilgaz ile "Neden?", Buket Güler ile "Mesele"); TRT 1'de 1 (Enine Boyuna) ve Ülke TV'de 2 (En Sira Dışı, Mustafa Yıldız İle 5. Gün) olmak üzere, toplam 31 tartışma programı oluşturmaktadır.

Olasılığa dayalı olmayan örnekleme tekniklerinden amaçsal örnekleme (purposeful sampling) türünün kullanıldığı çalışmada, Habertürk ve CNN Türk TV kanallarında yayımlanan ve yayın sürelerinin tamamını veya büyük bir bölümünü yalnızca II. Karabă̆ Savaşı konusuna ayırmış olan, ayrıca içeriğinde konuşmacıların söylemlerinde çarpıtma unsurlarının bariz biçimde tespit edildiği tartışma programlarının bölümleri dikkate alınmıştır. Dolayısıyla çalışmanın örneklemini Habertürk TV'den Kübra Par'la Açık ve Net programının 28 Eylül 2020 ve Eren Eğilmez ile Gerçek Fikri Ne? programının 3 Ekim 2020 tarihinde yayınlanmış bölümleri ile; CNN Türk TV'den Semiha Şahin'le CNN Türk Masası'nın 3 Ekim 2020 ve Ahmet Hakan'la Tarafsı Bölge programının 19 Ekim 2020 tarihli bölümleri oluşturmaktadır.

\section{V. Çalışmanın Sınırlılıkları}

Çalışmanın yöntem kısmında tartışma hileleri ve çarpıtma unsurları konusunda belirlenmiş olan çözümleme kategorilerinin tamamının materyalin analizine yansıtılamamış olması, bizzat çözümlenen içeriğin sunduğu verilerin niteliğiyle ilgili ciddi bir sınırlılıktır. Aynı şekilde, retorik çözümlemede dikkate alınan unsurların (tanımlama, metafor ve metonimi kullanımı, lakap kullanma, sürü mantığı yaratma, örtmeceye başvurma, korku ve endişe uyandırma, dramatizasyon, kanıt gösterme, vb.) bazılarına ulaşılamamış olması da çalışmanın bir diğer sınırlılığını oluşturmaktadır. Üçüncü olarak, çalışmanın örneklemini oluşturan televizyon programlarının kimi bölümlerinin eşzamanlı olarak yayına girmesi nedeniyle, bu bölümlerin aynı anda bir tek araştırmacı tarafından dikkatli bir şekilde izlenme olanağının olmaması da altı çizilmesi gereken bir başka zorluktur. Nitekim hem CNN Türk, hem de Haber Türk TV kanallarının yayın saatleri büyük ölçüde birbiriyle çakışmaktadır ve bu sorun elden geldiğince ikili bir izlemeyle -iki yazar arasında yapılan işbölümüyle- aşılmaya çalışılmıştır. 


\section{Retorik, Medya ve Tartışma Programları}

\section{A. Retorik Kavram Alanı ve Kavramın Tarihsel Gelişimi}

Retorik, geçmişten bugüne farklı biçimlerde ve özelliklerle tanımlanmış olsa da, kavramın hâlâ kesin bir tanımının veya ortak kabul görmüş bir izahının olduğunu söylemek güçtür. Genel olarak inandırma, ikna etme, etkili konuşma yolu ile ele alma bilimi veya sanatı olarak tarif edebileceğimiz retorik, zaman zaman hem yararlı ve yüce, hem de oldukça yararsız görülen bir kavram mahiyetine sahip olmuştur. Antik Yunancada 'rhetor' kelimesi 'konuşmacı' anlamına gelirken, bu sözcükten türemiş 'rhetorike' veya 'rhetorikos', insanlara hitap etmek anlamını ihtiva eder. Yanı sıra, retorik 'güzel söz söyleme, etkileme, belagat, ikna' ve bu ikna sürecinin sonucunda 'tabi kılma' anlamını da içerir (Duman, 2015: 59-60). Diğer taraftan 'söylenilmiş olan', 'söz' şeklinde de tercüme edilebilen 'rhetos', retorik kavramının temelini teşkil eder ve buradaki 'ik' eki Grekçedeki -ilk olarak Gorgias'ın da kullanmış olduğu şekli ile'rhetorike techne'ye karşılık gelir. Kelimenin, Latinceye 'rhetorica', 'ars rhetorica', 'ars oratoria', 'ars persuandi', 'eloquentia', İngilizceye 'rhetoric', Fransizcaya 'rhetorique', Almancaya 'rhetorik' olarak geçtiği belirtilebilir (Tepebaşılı, 2016: 15). Bu kelimenin Arapçaya tercümesinde 'rituriyye' şeklinde ele alındığı, Arap-İslam coğrafyasında Meşşai felsefenin ${ }^{1}$ ilk üyesi olan Kindi'nin Risaleler'inde retoriğe 'riturika', daha sonra ise 'el-belaği' şeklinde karşılık getirilmiştir. Fakat belagatin, edebi olarak güzel söz söyleme anlamına geldiği, retoriğin ise bir konuşma, güzel söz söyleme kültüründen çok iknaya, inandırmaya yöneldiği göz önünde bulundurulursa bu kelimenin, tam anlamıyla retoriğe denk gelmediği anlaşılır. Bu nedenle Arap düşünürler, sonrasında retoriği, 'elhatabe' ile daha çok anmaya başlamış ve onu bir hitap etme, hatiplik sanatı, hitabet olarak görmüşlerdir (Coşkun, 2014: 57-58). Burada Latincedeki 'rhetorica' ve 'oratoria' ('eloquentia') kavramlarına da değinmek gerekir. Roma döneminde retoriğin teorik tarafı 'rhetorica' olarak anılırken, pratiğe dayanan yönü 'oratoria' veya 'eloquentia' şeklinde adlandırılır. Yani kendi içerisinde bile retorik için belirli sınırlar çizilir. Arapçadaki 'belagat' kelimesinin ise Latincedeki 'oratoria' ve 'eloquentia' sözcüklerine denk gelmesi tesadüf değildir. Retorik kavramının Arapçada ilk kullanıldığı zamanlarda Roma kültüründeki pratik retoriğin temel alındığı iddia edilebilir. Bu kelimenin Türkçedeki kullanım şekillerine gelecek olursak, tam anlamıyla kesin bir karşılığının olmadığını, lakin 'söylev', 'hitabet', 'ikna etme sanatı', 'etkili söz söyleme sanatı' gibi anlamlarda kullanıldığı vurgulanabilir. Ayrıca bir konuşmayı veya yazılı çağrıyı yerine getirenler, yani 'rhetor'lar da 'söylevci', 'hatip', 'söz sanatı ustası', 'konuşmacı', 'aytaç' gibi sözcüklerle anlatılırlar (Dürüşken, 2001: 3).

Aristoteles'in, hocası Platon'dan farklı olarak 'nous', yani akla değil; 'psyche'ye yani ruha- daha çok önem verdiğinden, retoriğin tanımında da insanları ruhen etkileyerek yönlendirilme gibi bir amacı esas aldığını söyleyebiliriz. Gerçek sanatın, konuşmacının tabiat bilgisinin yanı sıra ruh bilgisine dayandığı, ruhların sınıfları ve türleri, onların

\footnotetext{
${ }^{1}$ Kısaca Aristo felsefesinin İslam fikir coğrafyasındaki karşıllığ olarak ifade edilebilecek olan Meşşailik düşünce geleneğinin özü, İslam inancı ile Aristo mantı̆̆ını kaynaştırmasıdır. Meşşai ekolünün başlica temsilcileri El Kindi, Farabi, İbn Sina ve İbn Rüşd'tür.
} 
TV Tartışma Programlarında Çarpıtma Unsurları: II. Karabağ Savașı (ErmenistanAzerbaycan Çatışması) Örneği

hangi etkilere sahip olduğu ve kendilerinin de nasıl etkiler doğurduğu, ayrıca sebeplerin ruhları nasıl etkilediğini aktarması, retorik kavramı ve tanımına dair genel düşüncelerinin bir özeti niteliğindedir (Murphy ve Katula, 2003: 31). Aristoteles, temelde Anaxagorasçı olması yüzünden 'nous'a önem verir ve Platon'un aksine, retoriği sistematikleştirilebilen, çerçevelere oturtularak öğrenilmesi mümkün alan bir olgu şeklinde tanımlar. Aristoteles'ten önce Platon'da da retoriğin türlerine rastlanılmaktadır. Gorgias'ta, hukuk alanındaki konuşmalarla örtüşen mahkeme retoriği, kitleler önündeki ikna gücü ile tanımlanan politik retorik, Menexenos'ta ise törensel retorikle kamusal konuşmaları kapsayan bir tür olarak anlatılır (Duman, 2015: 80-81).

Retorikle ilgili hem Antik Çă̆ hem de ondan sonraki dönemler için temel kaynak rolünü üstlenen tezleri bir araya toplamış olan Aristoteles, retoriği iknayı gerektiren veya ikna etmeyi amaçlayan kanıtlar ve söylemlerin sergilenmesi olarak tanımlar (Aristo, 2014: 19). Üç kitap halinde basımı gerçekleştirilmiş olan Retorik'te, Aristoteles'in bu konudaki bütün bakış açılarını ortaya koyabilmiş olduğu söylenebilir. Burada retoriğin, faydalı olduğu gibi zararlı bir güce sahip olduğu da gündeme getirilir. Aristoteles'in gözünden retorik, diyalektiğin muadilidir ('antistrophos'). Düşünüre göre, üç tür retorik vardır: Herhangi bir şeyi yapmayı veya yapmamayı nasihat eden, daha çok geleceğe yönelik 'politik retorik' (symbuleutikos); mahkemelerde savunma veya suçlama yapmak için kullanılan, genellikle geçmişte yaşanmış olaylarla ilgili olan 'adli retorik'; ve son olarak, şimdiyi - içinde olduğumuz dönemi- anlatan, ayrıca içinde övgü veya yergi barındıran 'epideiktik (törensel) retorik' (Aristoteles, 2014: 20). İslam dünyasında, Meşşai felsefenin üyeleri de Aristoteles'in Retorik metnini çevirir ve yorumlarken aynı sistemi kullanmışlardır. Fahreddin Razi, Şerhu Uyunu'l-Hikme'de retoriği, akaid ve amelle ilgili olarak ikiye ayırır. Burada akaid açısından retorik, hitabet aracı ile Allah'a ve ona inanmaya davet şeklinde kavranırken; amelle ilgili kısımlar tıpkı Aristoteles'teki gibi siyasetle, şikâyet ve savunmayla, övgü ve yergi ile (münafiriyye) temsil edilir (erRazi, 1415: 252'den akt. Coşkun, 2014: 217-218). Aristoteles'in, retoriği tanımlama ve ona ait kavramlarla bağlantıll, önemli bilinen noktalardan biri de konuşmacının, hangi özelliklere sahip olarak ve neleri kullanarak karşısındakileri inandırma yöntemlerine başvurduğudur. Öncelikle konuşmacının kişiliğinin dinleyiciler açısından güvenilecek bir karaktere sahip olunmasını gerektiren 'ethos' devreye girer. Daha sonra hatibin, konuşma ile duygulara yüklenme ve karşısındakileri duygusal açıdan ele almayı hedefleyen 'pathos'; en sonda ise retoriğin dil ve üslup, bilimsel ve mantıksal açıdan dayanıklı temeller üzerinde kurulması şartı olarak 'logos' önem taşır (Aristoteles, 2014: 19). Temel olarak ifade ve kanıt şeklinde iki bölümden oluşan retorik konuşmalarına, giriş ve epilog kısımlarının eklenmesi de mümkündür. Ayrıca Theodoros'un benimsediği yolu izleyenlerin tasnifini de aktaran Aristoteles, retoriğe ön anlatı, ek anlatı, çürütme ve ek çürütme bölümlerini de dâhil eder (2014: 202-206).

Retorik sanatı ve biliminin önemli gelişme kaydettiği Roma döneminde ise retoriğin esas temsilcileri Cicero ve Quintilianus'tur. Cicero, Isocrates'ten yola çıkarak, konuşmanın insanlara faydalı olabilecek şekilde anlatımını üstün tutmuştur. Onun, hatibi yüksek bir mertebeye yerleştiren, konuşmayı ise ruhları besleyen veya onları yücelten bir kraliçe gibi tanımladığı bir vakıadır. Konuşmacının ahlaklı, eğitimli, erdemli, evrensel bir insan (homo universale) olmasının önemini vurgulayan Cicero, retoriğin 
yalnızca pratik bir olay olmadığı, teorik açıdan da ele alınabileceğine inanır. Ayrıca Cicero'nun, retoriği politikanın bir parçası olarak gördüğü, etikle politika, kuramla pratik, filozoflarla hatip, eğitimle kamusal konuşma arasında bir ortak nokta bulma çabasında olduğu söylenebilir (Tepebaşıll, 2016: 16, 131). Cicero gibi Quintilianus da iyi ve erdemli konuşmacı tipi ile faydalı ve güzel söz söyleme sanatını retoriğin tanımı içine alır. Hatta Quintilianus'un kendi dönemine göre oldukça ileri düşüncelere sahip birisi olarak, insanın yalnızca kitlesel olarak mevcudiyetini koruyan bir varlık olmasına karşı çıktığı da söylenebilir. Mükemmel bir insanın mükemmel konuşabilen birisi olduğuna inanan Quintilianus'un, bu yüzden retorik eğitimini önemli gördüğü ve insanların çocukluktan itibaren retorik eğitimi almaları gerektiğini savunduğu söylenir (Dürüşken, 2001: 88, 112). Rönesans'ta Hümanist düşünceye uygun olarak Isocrates, Cicero veya Quintilianus'un öğretilerine geri dönen retoriğin, Aydınlanma Çă̆ı'nın ardından, XIX. yüzyıl burjuva toplumunda önemini büsbütün kaybettiği, XX. yüzyılda ise yerini yeni bilimlere, tezlere ve teorilere - Hans-Georg Gadamer'in 'hermeneutik'i, Jürgen Habermas' 'n 'iletişim becerisi', Roland Barthes ve Umberto Eco'nun 'semiyotikdilbilimsel retoriği’ vd. - bıraktığı söylenebilir rahatlıkla (Tepebaşıllı, 2016: 19-20, 139157). Hiç kuşkusuz, kitle medyası ile birlikte de, retoriğin kitlelerin yönlendirilmesi, ikna yoluyla kontrol edilmeleri gibi etkilerinin ve işlevlerinin keşfiyle birlikte yeniden sosyal teoride ve medya analizlerinde önem kazanmış olduğunun altı çizilebilir. İzleyen bölümde çarpıtma olgusu, retorik kullanımında başvurulan dilsel çarpıtma unsurları ve tartışma hileleri gibi kavramların izahı yapılmaya çalışılmıştır.

\section{B. Çarpıtma Kavramı, Çarpıtma Unsurları ve Tartış̧a Hileleri}

Aristo'cu retorik kavrayışından hareketle söylenirse, çarpıtma, en yalın biçimiyle, tartışma süresi içinde kendi doğrularını kanıtlamaya, muhatabını ve/veya muhatapları ile hitap ettiği kişileri ikna edebilmek için mutlak hakikat açısından yanlış olan inandırma tekniklerini kullanmaya, bilgiyi doğru olmayan bir yere doğru sürüklemeye dayanan bir tartışma biçimidir (Aristo, 2014: 143-160). Bu anlamda, yine Aristo'ya göre, retorik de "yargıyı coşkularla saptırmaya başvurma" işidir (2014: 19). TDK Türkçe Sözlük’te de İngilizcedeki 'distortion' sözcügü; "Çeşitli koşullanma, önyargı, eğilim ve etkilenmelerden ötürü gözlemlerin çarpık biçimde algılanarak saptanması" olarak tanımlanmıştır. Bu tanımdan da hareketle denebilir ki, çarpıtma, ister yazılı isterse sözel ve görsel olsun, var olan gerçekliğin farklı etkilenmeler ve amaçlarla bağlamından saptırılması durumudur.

Retoriğin çarpıtmayla ilişkili yanı ise, doğrudan eristik konuşma biçimiyle ilgilidir. Alman düşünce dünyasının önemli isimlerinden Arthur Schopenhauer da, Aristo'cu tartışma biçiminde başvurulabilecek hilelere atfen 'eristik diyalektik' ifadesini kullanır. Düşünürün eristik diyalektik dediği şey, aslında didişmek suretiyle tartışma icra etmenin ta kendisidir. Bu durumda, tartı̧̧mayı yürüten kişi, ister haklı ister haksız olsun, tek amaç olarak haklı çıkmaya ve bunun için de türlü çarpıtmalara girişir (Schopenhauer, 2012b: 5). Schopenhauer, tarafların hakikate sadık kalmayarak, kendi doğrularını göze sokma kaygısıyla yönlendirilen tartı̧̧a sanatındaki çarpıtmayı, bir kılıç ustasının, düelloya sebebiyet verenin haklı veya haksız olmasının önemine dikkat göstermeden, yalnızca 
TV Tartışma Programlarında Çarpıtma Unsurları: II. Karabağ Savașı (ErmenistanAzerbaycan Çatışması) Örneği

hamleleri savuşturmak için elinden geldiğince karşı hamle gerçekleştirerek kendisini korumasina benzetir (2012a: 13).

Eristik diyalektik kavramındaki 'eris'in isim köküne baktığımızda ise, Antik Yunan mitolojisinde anlaşmazlıklar, kavga ve bozgunu temsil eden tanrıça Eris'in olduğunu görürüz (Berens, 2009: 96). Bu anlamıyla eristik tartışma, kavgacı bir müzakere etme biçimidir. Yukarıda da değinildiği üzere, Aristo'cu eristik diyalektik kavrayışı açısından böyle bir tartışma biçiminde, konuyu veya bilgiyi çarpıtmada kullanılan hileler sırasında birçok taktik betimlenmiştir. Yanlış önerme kullanma, karşı tarafı kendi silahı ile vurma, zorluk çıkarma, tartışmayı kesme, anlamazdan gelme, alay yolu ile karşı tarafin yetersizliğini gösterme, sorunun sebebi yerine otoritelerin etkisini savunma, vb. bunlardan sadece bazılarıdır.

Televizyon tartışmalarının yanı sıra, günümüzde daha sık görülen ve çoğunlukla sosyal medya platformları üzerinden gerçekleştirilen tartışmalarda da aynı durum söz konusudur. Tartışma sırasında tarafların, birbirlerini dinleyip fakat düşüncelerini anlamadan, bir tehlikeyi savuşturur gibi hemen savunmaya geçtikleri sırada, çarpıtmaya, bilgiyi saptırmaya, onu farklı yöntemlerle doğru gibi göstermeye çalışma yönündeki eğilimleri, tartışmalardaki başlıca çarpıtma unsuru örnekleridir. Ortaya doğru bilgi yerine inanılması olası olan bilgiyi koyduğumuzda, sorunun medyanın başat problemlerinden birisi olan dezenformasyona doğru yol aldığı da hemen görülebilir. Zira yalan haber, asılsız beyanlar, çarpıtılmış veya bağlamından saptırılmış bilgiler, vb. hem kafa karıştırmada hem de bilgi kirliliğine yol açmada etkili bir role sahiptir (Sarı, 17.07.2020).

\section{Tartışma Programı Sınıflandırmaları ve Türkiye Televizyon Ekranlarında Tartışma Kültürünün Gelişimi}

Öncelikle göstergebilimci Umberto Eco'nun açık yapıt, karnaval teorisi ile tanınan Mikhail Bakhtin'in ise dialojik bir metin olarak gördüğü tartışmaların, televizyon kanallarındaki farklı türlerini incelemek gerekir. İletişim bilimci Erol Mutlu'nun sınıflandırmasına göre (1995: 113-115), tartışma programları aşağıdaki gibi ayrımlanabilir;

1. Sempozyum: Bu tip tartışma programlarında kesin hatları ile bilinen bir sorun üzerine ciddi çalışmalar yapmış kişiler davet edilirler. Uzmanlar, genellikle konuyla ilgili bireysel açıklamalar getirebilen kişilerden oluşur. Eşit zaman çerçevesinde davetli konuşmacılar kendi görüşlerini aktardıktan sonra izleyicilerin soruları da alınır. Aslında sempozyumun tarihi de tartışmanın kökeni gibi unsurların kökleri de Eski Grek kültürüne dayanır. 'Birlikte içmek' veya 'resmî yemek' anlamına gelen 'symposion', katılımcıların şarap içerek şiirsel ve retoriksel anlamda birbirleri üzerinde zafer elde etmelerine olanak sunan birer resmi içki törenidir (Gürer, 2014: 94-95).

2. Panel: Panel tartışma programlarında dünya, doğa, toplumla bağlantılı bilgi ve düşünceleri artırmak için çalışılır. Panel izleyicilerinde duygusal ve düşünsel anlamda merak uyandırılır. İkna ve etkilemenin üstün olduğu bu tür tartışmalara aynı zamanda seçilmiş bir grubun, izleyicilerin önünde farklı konularla ilgili fikirlerini yarıştırmak amacı ile düzenlenmiş bir toplantı veya açık oturum gibi bakılabilir (Moran, 1992: 535). 
3. Grup Tartışması: Bu tartışmaların belirli bir sorun hakkında ortak çalışmalar sonucunda çözümün bulunmasına yönelik arayışları betimlediği söylenebilir. Bu türün farklı bir özelliği de, katılımcıların objektif, işbirliğine sadık şekilde davranmaları zorunluluğudur.

4. İzleyici Katılımı IV Tartışmaları: Bu tür programlar ise, uzman görüşlerinin izleyici fikirleri, daha doğrusu soruları ile sentezlenmesine dayanır. Bu anlamda, izleyici katılımlı TV tartışma programlarının aslında iki türü ayırt edilebilir. İlkinde, profesyonellerin fikirlerini aktarmasıyla birlikte, izleyicilerin sorularına yanıt verilmesi sağlanır. İkincisinde ise, öncelikli olarak izleyici soruları alınır ve tartışma, büyük ölçüde izleyici görüşlerinin değerlendirilmesine adanır. Bu tür sınıflamanın, uzman-izleyici kategorilerinin söz sırası üzerine kurulduğu söylenebilir.

TV tartışma programlarının en yaygın türü olarak genellikle açık oturumlar kabul edilse de, bu tartışma türlerinin de kendi içinde birkaç farklı örneğinin olduğu söylenebilir. Bu örnekler Gökçe'nin yaptığı sınıflamaya göre (1997: 212) kısaca aşağıdaki gibidir:

i. Olağan Oturumlar: Birbirine zıt fikirlere sahip kişilerin katılımı ile gerçekleşen olağan açık oturumlarda herhangi bir konu tartışılabilir.

ii. Basın Toplantısı: Genellikle ünlüler veya public figure diye tabir edilen kamuya mal olmuş ünlü kişilerle birbirlerinden farklı görüşlere sahip katılımcılar tarafından soruşturma havasında gerçekleştirilen bir tartışma türüdür. Önemli kişi olarak addedilen katılımcının, kendi sorumlulukları ve ağırlığını unutarak tartışma havasına girmesi, bu tartışmanın başarısını gösterir.

iii. Takım Tartışması: Bu türde, konuların tartışılması için her hafta veya her bölümde farklı uzmanların davet edilmesinin mümkün olmadığı esas alınır. Belli kriterler çerçevesinde zamanla kurulmuş bir grup tarafindan her defasında farklı konuların tartışılması hedeflenir.

iv. Seyircili Oturumlar: İzleyicilerin etkin olduğu, her an tartışmaya katılacak halde hazır bulunduğu bir açık oturum türüdür. İki kamera aracılığı ile yönetilmesi güç olan bu türde, tartışma ortamı konuşmacılar ve izleyiciler arasında oluşur.

v. Söz Seyircinin: Belli bir konu etrafında tartışma yürüten bir grup kişiye stüdyodaki izleyicilerin sorular sorması üzerine kuru bir tartışma türüdür.

vi. Olayların İçinden: Güncel olaylar hakkındaki görüşleri barındıran, seçim, bütçe meseleleri, savaş, vb. konuları içeren bu türün aslında çalışmamızın konusunu oluşturan tartışma tarzına uygun düştüğü söylenebilir.

\section{TV Tartışma Programı Yayın Süreci Așamaları}

Tartışma programları, genel anlamda belli bir ilerleme senaryosuna sahip TV programı türleridir. Yani bir tartışma programı süreci, özel durumlar dışında aşağı yukarı benzer bir hat üzerinde devam eder. Bu hat Məmmədli’ye göre (2012: 140-142) kabaca şu şekilde formüle edilebilir: 
TV Tartışma Programlarında Çarpıtma Unsurları: II. Karabağ Savașı (ErmenistanAzerbaycan Çatışması) Örneği

1. Tartışmanın Başlangıcı: Bütün türlerde olduğu gibi burada da izleyiciler en başından beri dikkate alınmalıdırlar. Moderatörün, konuyu takdimi ve esas hipotezleri seslendirmesi ile program akışı başlar. Bu aşama, en önemli aşamadır, çünkü konu veya tezlerin güçlü, ilginç, merak uyandıran bir nitelikte olması, seyirciyi ekran başına toplamada birer vitrin rolü üstlenir. Moderatörün konuşması akıcı, kendinden emin ve rahat olmalıdır. Daha sonra katılımcıların tanıtılması ile konunun tartışılmasına geçilir ve böylece giriş bölümü tamamlanmış olur. Ayrıca giriş kısmı ne kadar kısa ve öz olursa seyirciyi yormaz ve daha çok etki üretir.

2. Tartışmanın Yönlendirilmesi: Burada yine en ağır yük moderatorün omuzlarındadır denilebilir. Tartışmanın, uzmanlar arasında ortak şekilde yapılması, katılımcıların konudan sapmasının önünün alınması, herkese eşit davranılması, tezlere dair bütün taraflar açısından görüşlerin belirtilmesine dikkat edilmesi, moderatörün uzmanlığını ortaya koyacak unsurlardır.

3. Tartışmanın Akışı: Her bir moderatör, sunmuş olduğu programın televizyonun haber ve zamanlama siyasetine uygun şekilde akışını sağlamakla yükümlüdür. Tartışmanın akış süresi boyunca programın kaliteli bir biçimde ilerleyip ilerlemediğine dikkat edilmeli, sorunlar varsa ortadan kaldırılmalı, monotonluk giderilmelidir.

4. Tartışmanın Sonu: Mantıksal kurallara dayanan bütün olaylar gibi tartışmanın sonucunda da seslendirilmiş fikirlerin özetlenmesi, nelerin konuşulup nelerin konuşulmadığı, tartışma sonunda nelerin öğrenildiği, sorunla ilgili hangi çözümlerin teklif edilebileceği dile getirilir ve bunların sonrasında program kapatılır.

Türkiye televizyonlarındaki tartışma programlarının kökenine gelince; her ne kadar ilk kez 1988-89 yıllarında TRT 1'de ekrana gelmiş ve Ali Kırca'nın sunumundaki Açık Oturum ile gazeteci Uğur Dündar'ın sunuculuğunu yaptığı Forum programlarına dayansa da, bu türün gelişimi esasen özel televizyon yayıncılığının başladığı 1990'lı yılların başlarına tarihlenmiştir denilebilir. Türkiye'nin ilk özel televizyon kanalı olan Star-1 ise (sonradan Magic Box), dönemin başbakanı Turgut Özal'ın oğlu Ahmet Özal'ın ortağı olduğu Liechtenstein kaynaklı Magic Box Incorporated şirketi tarafından desteklenmiştir. 1990 yılından itibaren yayına başlayan, Körfez Savaşı’nın canlı yayınını CNN kanalı üzerinden Türk izleyicilerine aktaran Magic Box'un ardından, çok kısa bir süre içinde özel televizyon yayıncılığının dikkat çekici bir gelişim gösterdiği vurgulanabilir (Gürer, 2014: 127-131). Yine bu y1llarda, Star-1'in yanı sira TeleOn, Show TV, TGRT, Kanal 6, Kanal D, HBB, ATV, Flash TV, Samanyolu, Kanal E, Cine 5, $B R T$, vb. özel televizyon kanallarının, fiili olarak ve hızlı şekilde gelişerek Türk televizyon yayıncılığı alanını bir anda kapladıkları kaydedilebilir (Kaya, 2016: 259). 90’lı yıllardan günümüze Türkiye televizyon tarihinde öne çıkan TV tartışma programı örnekleri ise şöyledir: 1992 yılında Reha Muhtar tarafından TRT ekranlarında sunulmuş ve yayın serüvenini sonradan Star TV ile Show TV'de devam ettirmiş olan Ateş Hattı; 1993-94'te Mehmet Ali Birand ve Can Dündar'ın 44 bölümlük programları Çapraz Ateş; 1994'te Hulki Cevizoğlu'nun Ceviz Kabuğu isimli programı; Ali Kırca'nın sunuculuğu ile 1994'te yayına başlayan, sonraki 20 yıl boyunca farklı kanallarda ekrana gelen, eşine az rastlanır bir açık oturum programı örneği olan Siyaset Meydanı, vb.(Ertuna, 2018: 66). Birkaçı istisna olmakla birlikte, Türkiye'de tecimsel niyetlerin baskın olduğu, kamu 
yararının aksine satışa, suni bir kültürel gündem üretimine destek veren özel televizyon yayıncılığının, büyük ölçüde tartışma programlarında da reyting yaratabilecek unsurları kullandığı söylenebilir.

\section{Bulgular}

\section{A. "Açık ve Net" Programı}

Çözümleme birimlerinin ilki, Habertürk TV'de yayınlanan "Açık ve Net" programının 28 Eylül 2020 tarihli bölümüdür. Kübra Par'ın moderatörlüğünde ekrana gelen yayın, II. Karabağ Savaşı ile ilgili tartışma ve değerlendirmelere yer veren program örneklerinden birisidir. Programın konu başlı̆̆ı, "Azerbaycan-Ermenistan Gerilimi: Türk Ordusu İçin Yeni Bir Cephe mi?" şeklindedir. Genel sunuşun ardından moderatör, sırasıyla emekli hava pilot korgeneral Dr. Erdoğan Karakuş, gazeteci-yazar Metin Özkan, Habertürk Güvenlik Politikaları Danışmanı Mete Yarar ve Sözcü gazetesi yazarı İsmail Saymaz'dan oluşan konuklarını takdim eder. Katılımcılardan Erdoğan Karakuş ve Metin Özkan yayına Ankara'dan bağlanmakta, Mete Yarar ve İsmail Saymaz ise İstanbul'daki stüdyodan katılmaktadırlar. Yayının 1. dakikasında İsmail Saymaz, moderatör Kübra Par'ın karşısındaki fotoğrafın lise yıllarından kaldığı yollu bir şaka ile söze başlar. Bunu, kuşkusuz bir çarpıtma biçimi olarak almamak gerekir, ancak bu minik şakanın ardından asıl dikkat çekici müdahale, Kübra Par'ın Erdoğan Karakuş'a konu ile ilgili dönüş yaptığı sırada, "Espri ile başladık ama durum gerçekten ciddi!" ifadesini kullanmasıdır. Sunucu durumun ciddiyetinin farkındadır ve konuğunun meseleye şaka ile giriş yapmasını pek de doğru karşılamamıştır. Burada, Saymaz'ın yaptığı şakanın, tartışmanın herhangi bir yerinde "muhatabın, konuşmanın bağlamını değiştirerek tartışmada [moral] üstünlük sağlayabileceği” yollu Aristo'cu eristik önermeyle doğrudan ilişkili olduğu söylenebilir (Schopenhauer, 2012a: 102). Espri yapmak ciddiyetten eksiltir, ama aynı zamanda zekâca bir tür üstünlük biçimidir de. Bu, aynı zamanda tartışmacının tribünlere (burada sunucuya) oynamak suretiyle avantaj elde etmek istediği bir durumdur. Tartışmanın başında Kübra Par'ın, yayının 8. dakikanın 19. saniyesinde, Erdoğan Karakuş'a yönelik olarak, savaşın askeri boyutları, harekâtın nereye kadar gidebileceği üzerine sorduğu soru üzerine Karakuş’un politik yorumlara kaydığı görülür. Karakuş'un burada yöneldiği çarpıtma unsuru, 'anlamazdan gelme'dir. Tartı̧̧macı, sunucunun sorusuna yanıt vermeyip, tartışmada odağı başka bir yöne kaydırarak çarpıtmaya başvurmaktadır. Aristo'nun da vurguladığı gibi, farklı örneklerle kanıtlama politik tartışmaya uygundur (2014:30), ancak kanıtlamanın bağlamı değiştiğinde, saptırma da kaçınılmaz olmaktadır. Sonuçta yayının 12. dakikanın 44. saniyesinde, moderatör konuğun sözünü keserek siyasi yansımalar üzerine ayrıca konuşulacağını, şimdi yalnızca askeri boyutları ele almaları gerektiğini hatırlatır. Par'ın bu konuda Erdoğan Karakuş’a söz hakkı tanıyacağı konusunda güvence vermesi, yayının başından itibaren gerilim yaşamak istenmediğini ortaya koyar. Ardından, yayının 48. dakikasında, konuşmacı Metin Özkan'ın konuyu alenen çarpıttı̆̆ı bir bağlam oluşur. "Türkiye artık eski Türkiye değil”" giriş cümlesinin ardından, Özkan; "Buradan 'eski Türkiye' lafımdan kimse de üzerine bir şey alınmasın” şeklinde azarla karışık bir çıkış yapar. Devamında ise, "Başkanlık makamında çekilen beysbol sopalı fotoğrafların, Türk askerinin kafasına çuval geçirilerek tehdit edilmesinin geride kaldığını" belirtir. Tam da bu esnada Özkan'ın 
TV Tartışma Programlarında Çarpıtma Unsurları: II. Karabağ Savașı (ErmenistanAzerbaycan Çatışması) Örneği

asıl tartışma konu başlığıyla ilgisi olmayan farklı bir söylev tutturduğu gözlenir. Zira burada tam da Aristo'cu eristik diyalektikte "tartışmacının daha önceki hataları, suçlamanın ya da savunmanın temeli yapmak" (Schopenhauer, 2012a: 133) diye yorumlanabilecek bir çarpıtma unsuru söz konusudur. Gerçekten de, Türkiye'de eskiden yapılmış yanlışlardan yola çıkarak, mevcut iktidarın güncel durumu ve değişimine veya gücüne dair övgüler düzülmesinin II. Karabağ Savaşı ile uzaktan yakından hiçbir ilgisi yoktur.

Yayının 58. dakikasında, Mete Yarar'ın Erdoğan Karakuş'un konuşmasına itiraz ederek savaşın adının "Ermenistan-Azerbaycan Savaşı" şeklinde anılmasını yanlış bulduğunu söylemesi üzerine hararetli bir tartışma başlar. Savaşın, Karabağ'daki sözde özgür askeri birlikler ile Azerbaycan Cumhuriyeti arasında olduğunu dile getiren Yarar'ın ardından, gazeteci İsmail Saymaz, Kübra Par ve Erdoğan Karakuş arasında kıyasıya bir tartışma alevlenir. Görüşlerin gitgide bulanıklaşması ve stüdyoda oluşan ses karmaşası üzerine, sunucu gülümseyerek "hepsi birbirine karıştı!" yollu bir serzenişte bulunur. Fakat gerçekte en azından olgusal olarak ortada herhangi bir anlaşmazlık yoktur. Meselenin adı, uzun yıllardan beri ve şimdi de Ermenistan-Azerbaycan Dağlık Karabağ sorunu olarak anılmakta olup, işgalcinin Ermenistan olduğu, savaşla ilgili Ermenistan Başbakanı, Savunma Bakanı ve diğer yetkililerin defalarca açıklamalar yaptığı bilinmektedir. Uzmanın kendi görüşünü dile getirmesi normal bir tavırdır, ancak yaklaşımı II. Karabağ Savaşı'nın güncel yorumundan uzaktır. Burada da tartışmacı Mete Yarar'ın kasıtlı veya kasıtsız biçimde diğer konuşmacılarla işbirliği içinde, sunucuya 'zorluk çıkarmak' suretiyle konuyu bağlamından saptırdığı bir durum vardır. Söz konusu zorluk, tartışmacıların iddialarının içeriğinden bağımsız olarak, Aristo'nun "kararlar vermeyi etkilemek" (2014: 97) için başvurulduğunu belirttiği eristik, yani kavgacı diyalektiktir. Kübra Par'ın, Mete Yarar'ın sözünü keserek ara vermek zorunda olduklarını, aradan sonra konuğun kesintisiz biçimde yorum yapabileceğini söylemesi üzerine, Yarar'ın, incindiği, elini sallayarak "nasıl isterseniz" diye hayıflandı̆̆ı, adeta konuştuklarının önemsiz görüldüğüne, kabul edilmediğine dair ima yüklü bir tavır sergilediği görülür. Yayının 1. saatinin 26. dakikasında, konuk Metin Özkan’dan apayrı bir yorum gelir. Özkan, hışımla; 'Ermenistan'ın Karabağ'da, İsrail'in Filistin'de, ABD ve Rusya'nın Suriye'de, Birleşik Arap Emirlikleri'nin Libya'da, Fransa'nın Yunanistan'da ne aradığını dile getiremeyenlerin, Türkiye'nin Karabağ olayında ne işi olduğunu söyledikleri iddiasının yersizliğine" dikkati çeker. Ne ki, konu başlığı çok geçmeden dağılır ve söz yeniden fütursuzca Türkiye'deki siyasetçilerin tavırlarına, eski Cumhurbaşkanı Abdullah Gül ile dönemin Ekonomi Bakanı Ali Babacan'a getirilir. Özellikle Gül'ün Ermenistan'a futbol maçı izlemeye gitmesi gündeme getirilir. ${ }^{2}$ Özkan, MHP Genel Başkanı Devlet Bahçeli ve Cumhurbaşkanı Recep Tayyip Erdoğan'ın, zamanında bu teşebbüsleri eleştirdiklerini hatırlatarak kendi siyasi eğilimini daha da belirginleştirmekte sakınca görmez. Burada özellikle vurgulanması gereken hususlardan biri, Özkan'ın ilgili haber başlıklarını zikretmesi, konuşmalarını somut kanıt ve göstergelerle sağlama alma çabası içinde olmasıdır. Bu ise, retorikte kanıtlamanın önemli unsurlarından olduğu kadar, konuyu farklı bağlamlar içinde çarpıtmaya da zemin

2 “Ermenistan Gül'ü Bekliyor”, https://www.cumhuriyet.com.tr, 10.09.2020. 
oluşturan bir durumdur. Özetle, Özkan'ın konuşmasında 'yanlış ve kasıtlı önermeler kullanma' durumu söz konusudur. Zira tartışılan konunun “Gül'ün Ermenistan'a futbol maçı izlemeye gitmesi”yle doğrudan bir ilgisi yoktur. Dahası, Özkan'ın gerek üst perdeden konuşma tarzı, gerekse muhataplarına hitap ederken bariz biçimde alaycı bir dil kullanması ("Sen bilmezsin, sen nereden bileceksin?", "Kaçırmışsın oraları, iyi takip edememişsin!", "Dur daha neler var, bu akşam hepsini öğreneceksin!”, vb.) dikkate alındığında, açıkça onları küçümseyici bir tavra sahip olduğu görülür. Küçümseme ise, dinleyicinin/seyircinin zihninde "bir şeyin açıkça önemsiz olduğuna değgin güçlü bir kanı" yaratır (Aristo, 2014: 99). Aynı şekilde, Gül'den 30 Ağustos'tan beri haber alınamadığına dair alaycı bir dokundurma yapan Özkan, Abdullah Gül'ün bu meselede sessiz kalıșını eleștirerek onu açıkça suçlar. Bu durumda moderatör, 2010'a kadar farklı bir siyasal çizginin yürütüldüğünü, o dönemde Türkiye-Ermenistan ilişkilerinin iyileşeceğinin beklendiğini hatırlatır. Ayrıca Abdullah Gül'ün son olayla ilgili Twitter'da bir dizi paylaşım yaptığı da açık bir kanıt olarak eklenir. ${ }^{3}$ Bunun üzerine Metin Özkan, eleștirel tavrını değiștirmez ve Gül'e karșı sert tavrını devam ettirerek, Gül'ün Ermenistan'a maç izlemeye gitmesinin bugünkü olaylara sebebiyet verdiği çıkarımını yapar. Bu dilsel manevra, konunun ne ölçekte çarpıtılabileceğinin adeta en kristalize olduğu anı verir. Çünkü burada, çifte bir çarpıtma durumu söz konusudur: Dilsel çarpıtmanın hem 'mantıksal benzetme', hem de 'rastlantısal olanı temel alma' unsurları bir aradadır. Özellikle ikincisi, Schopenhauer'in Aristo'cu eristik diyalektik kavrayışından çıkardığı sonuçlardan birisidir. "Kanıtlamada bir başak yol" diye yazar düşünür, "rastlantısal olanı temel olarak almaktır" (Schopenhauer, 2012a: 156).

Yayının 93. dakikasında yine Metin Özkan'ın konudan uzak bir örnek vermek suretiyle, Cumhuriyet Halk Partisi'ne hiciv içerikli bir göndermede bulunduğu görülür. Savaş sırasında Azerbaycan'ın tehlikeli de olsa sonuna kadar ilerlemesi gerektiğini savunan Özkan, Afrin Harekâtı sırasında CHP'nin Afrin'e girilmemesi gerektiğini, girilirse iki kilometre dahi ilerlenemeyeceğini deklare eden 'tarihi' yanılgısını hatırlatır kınayıcı bir dille. Özkan, birbirinden farklı iki olayı aynı özdeşlik içinde kavramayı salık verirken, aslında konuşmasını başka bir çarpıtma unsuruyla yoğurmakta gibidir. Söz konusu çarpıtma unsuru, 'bir olayın asıl nedeni olmayan şeyi o olayın gerçek nedeni olarak sunma'dır. Zira tartışmada önemli çarpıtma unsurlarından birisi de "[bir] olayın nedeni olmayan şeyleri, söz konusu olayla birlikte ya da ondan önce meydana geldiği için neden olarak göstermektir" (Schopenhauer, 2012a: 157). Özkan, diğer siyasi partilerin de buna benzer yorumlarda bulunduklarını ifade etse de, açıkça ismini zikrettiği tek kurumsal failin CHP olması dikkat çekicidir. Bir ara, YouTube üzerinden gelen izleyici yorumlarında konunun nasıl olup da Karabağ Savaşı'ndan bir anda CHP'ye geldiği sorularının sorulduğu aktarılır. Yayında diğer bir konudan sapma unsuru da, İsmail Saymaz'ın AK Parti üyelerinin uluslararası kriz başlayacağı sırada muhalefeti bu krizin uzantısı olarak göreceklerine dair görüşünü belirtmesi üzerine somutlaşır. Dolayısıyla aynı çarpıtma unsuru burada da devreye girer. Bu konudaki asıl hararetli tartışma ise, Saymaz-Özkan arasında yaşanır. Yayının 113. dakikasında, Saymaz

\footnotetext{
3"Herkesin Unuttuğu Abdullah Gül, Ahmet Davutoğlu Detayını Hatırlattı", http://www.yenicaggazetesi.com.tr, 30.09.2020.
} 
TV Tartışma Programlarında Çarpıtma Unsurları: II. Karabağ Savașı (ErmenistanAzerbaycan Çatışması) Örneği

kendisini ve eğilimlerini savunmaya izin verilmediğini, diğer tartışmacıların bir dakika söz isteyip genellikle on dakika konuştuklarını belirterek, sert ve ajitatif yorumlar yapan Özkan'a eleștiriler yöneltir. Ne var ki, Metin Özkan benzer tavrını sürdürür ve dahası iktidardan olmayan politikacılara yönelik olarak; "Kayserililer diyor ki, burnumdaki bene laf eden, önce gözünün önündeki çapağ görecek" şeklinde bir özdeyiş cümlesi bile sarf eder. Söylevdeki iddiayı daha da güçlü kılmak adına özdeyiş kullanma unsuru, Aristoteles retoriğinde de mevcut olup, bir çarpıtma unsuru olarak işlev ve etkilerinin hâlâ geçerli olduğunu gözlemlemek oldukça şaşırtıcıdır (2014: 136-139). Yayının en uzun süren içerik kayması, 109. dakikadan itibaren başlayıp tartışmaların sonlandırılmasına kadar devam eden bölümde gözlenir. Bu süre zarfında Karabağ sorunu, zaman zaman açıkça dile getirilse de, genel eğilim, Türkiye'nin diş politika stratejisi, onun çıkarları ve özellikle iktidar partisinden olmayan siyasetçilere dair ayıplayıcı, kınayıcı ve yer yer de suçlayıcı tartışmalar niteliğindedir. Olgusal olarak bölgede bir savaşın yaşanıyor olması, Türkiye'nin bu meseledeki konumu, uluslararası tepkiler, vb. tartışmanın genel boyutları olarak zikredilebilir, ancak genellikle partiler ve siyasetçiler üzerinden kurulan tartışmanın, çarpıtma niteliğinde çok farklı bir yönelimi yansıttığı söylenebilir. Burada hemen şunu da tespit etmek gerekir ki, konunun Erdoğan Karakuş tarafından 15 Temmuz askeri darbe kalkışmasına dek götürülmesi de en uç çarpıtma örneklerindendir. Söz konusu yayın, aralar hesaplanmaksızın 2 saat 32 dakika 48 saniye devam etmiş, toplamda $7 \mathrm{kez}$ asıl konunun çarpıtıldı̆̆ gözlenmiş ve bu çarpıtmalar, toplamda 58 dakika 22 saniye sürmüştür. Bu konudaki ayrıntılı bilgi rakamlarla Tablo 1'de gösterilmiştir (“Açık ve Net”, 28.10.2020).

Tablo 1: “Açık ve Net" Programının 28 Eylül 2020 Tarihli Yayınındaki Çarpıtma Unsurlarına Dair Detaylar

\begin{tabular}{|c|c|c|}
\hline $\begin{array}{l}\text { Çarpıtmanın Başlangıç ve Bitiş } \\
\text { Süresi }\end{array}$ & $\begin{array}{c}\text { Çarpıtmanın } \\
\text { Gözlendiği Toplam Süre }\end{array}$ & $\begin{array}{l}\text { Çarpıtma Yapan Konuşmacı veya } \\
\text { Konuşmacılar }\end{array}$ \\
\hline $11: 30-13: 08$ & 1 dakika 38 saniye & Erdoğan Karakuş \\
\hline $48: 48-49: 59$ & 1 dakika 11 saniye & Metin Özkan \\
\hline $58: 51-1: 06: 12$ & 6 dakika 20 saniye & $\begin{array}{c}\text { Mete Yarar, Erdoğan Karakuş, İsmail } \\
\text { Saymaz }\end{array}$ \\
\hline $1: 26: 18-1: 30: 00$ & 3 dakika 42 saniye & Metin Özkan \\
\hline $1: 32: 01-1: 32: 20$ & 19 saniye & Metin Özkan \\
\hline $1: 39: 10-1: 42: 01$ & 2 dakika 51 saniye & Metin Özkan \\
\hline $1: 49: 25-2: 31: 45$ & 42 dakika 20 saniye & $\begin{array}{l}\text { Mete Yarar, Kübra Par, Erdoğan Karakuş, } \\
\text { İsmail Saymaz, Metin Özkan }\end{array}$ \\
\hline
\end{tabular}




\section{B. “Gerçek Fikri Ne?” Programı}

Habertürk TV'de, Eren Eğilmez'in moderatörlüğünde yayımlanan “Gerçek Fikri Ne?" isimli programın 2 Ekim 2020 tarihli bölümünün konu başlı̆̆ "Ermenistan Geri Adım Atacak mı?" şeklindedir. Programda, İstanbul stüdyosundan CHP 22. Dönem Milletvekili Berhan Şimşek, AK Parti 22. Dönem Milletvekili Resul Tosun, gazeteciyazar Cem Küçük; Ankara stüdyosundan ise 24. Dönem Iğdır Milletvekili ve TÜRKSAM Başkanı Dr. Sinan Oğan konuk olarak katılmışlardır. Programın 23. dakikasında, Berhan Şimşek, "Açık ve Net” programında Metin Özkan tarafından sarf edilen söze atfen, Abdullah Gül'ün Ermenistan seferini dile getirir ve Gül'ün bu eyleminin "İki devlet bir millet" şiarına zarar verdiğini belirtir. Şimşek, Türkiye'nin geçmişte SSCB esaretinden kurtulan Türk ülkelerine ya darbecileri ya da FETÖ’cüleri gönderdiğini, bu yüzden Türk devletleri ile sağlam ilişkilerin bir türlü sağlıklı biçimde tesis edilemediğini iddia eder. Bunun üzerine, Resul Tosun'la Berhan Şimşek arasında politik tecrübelenin genişliği, olaylara hâkim olma ve Abdullah Gül'ün Ermenistan ziyareti gibi konular üzerine sert bir tartışma başlar. Yaklaşık iki dakika kadar süren tartışmada Şimşek, adeta Gül'ün hatasını gözlere sokmaya, Tosun ise bunun o kadar da büyük bir mesele olmadığını kanıtlamaya çalışır. Şimşek'in bu konular üzerine daha sonra görüş beyan edeceğini söylemesi ve moderatör Eren Eğilmez'in müdahalesi ile tartışma daha fazla büyümeden sonlandırılır. Burada Şimşek'in kendi iddialarını ileri sürerken başvurduğu eristik yöntemin 'bir olayın asıl nedeni olmayan şeyi o olayın gerçek nedeni gibi sunmak' olduğu söylenebilir (Schopenhauer, 2012b: 157).

Ardından Cem Küçük, Ünal Çeviköz'ün Türkiye'nin savaş bölgesine silah ve cihatçı gruplar gönderdiğine dair açıklamasını gündeme getirir ve bu tarz retoriğin Batı tarafından çarpıtılmasının normal olduğunu ima eder. ${ }^{4}$ Çeviköz meselesine yayının ilk birinci saatinden itibaren Sinan Oğan'ın da dâhil olduğu görülür. Oğan, Çeviköz’ün açıklamasını "akıl tutulması" olarak nitelendirerek, CHP ve Çeviköz'ün tutumları arasında ciddi farklılıklar bulunduğunu vurgular. Oğan'ın Ünal Çeviköz'ü ve televizyon ekranlarında yanlış ifadeler kullanan uzmanları eleştirmesi üzerine, Berhan Şimşek, üslup, yaklaşım, ifade, vb. tutum ve tavırları hatırlatmaya koyulur. Bu arada, Cem Küçük ve Resul Tosun da söz alma düzenine riayet etmeyerek, sözlü müdahalelerde bulunarak esas sıcak konunun kenarda bırakılmasına katkıda bulunurlar. Küçük ve Tosun'un her ikisi de burada 'zorluk çıkarma' eğilimindedirler -ki, bu da bağlamı saptırmaya dönük önemli bir tartışma hilesidir. Şimşek’in, tartışmayı AK Parti’nin siyasetine, mezhep ayrımcılığına, "Alevi”, "Kürt”, "Zaza" meselelerine getirmesi ile tartışma daha farklı bir boyut kazanır ve Şimşek ile Tosun arasında AK Parti-CHP kavgası halini alarak adeta bir söz düellosuna dönüşür. Ardından Küçük de içeriği saptıran bu sürece kendi 'argümanlarıyla' dâhil olur. Bura da yine tartışmacıların her biri, 'muhatabın iddiasını bağlamsız sınırların ötesine dek genişletme' eğilimindedir. Bunun da nedeni, Schopenhauer'in formüle ettiği biçimiyle, "ispat edilmesi gereken önermeyi farklı bir kılık altında kanıtlanmış saymaktır” (2012b: 94).

\footnotetext{
4 "Emekli Büyükelçi ve CHP Genel Başkan Yardımcısı Çeviköz: Türkiye'den Azerbaycan'a Silah Yardımı Yapıldığı İfade Ediliyor”, https://tr.sputniknews.com, 28.09.2020.
} 
TV Tartışma Programlarında Çarpıtma Unsurları: II. Karabağ Savașı (ErmenistanAzerbaycan Çatışması) Örneği

Moderatör Eğilmez, bu tür sapmaların her ne kadar esas tartışmanın ekseninden uzaklaşmasına neden olduğunu dile getirse de, girişimi bir yarar sağlamaz. Yayının 83. dakikasından itibaren sözün Trump-Kobani olaylarına getirilmesi ile II. Karabağ Savaşı müzakeresi sona erdirilir. Öncesinde az çok asıl konu tartışılırken ve ekranda savaşla ilgili “Ermenistan'ın Karabağ'ı İşgali” alt yazısı geçerken, Eren Eğilmez'in, Trump’ın hastaneye kaldırılması ve ABD'deki meseleleri araya sıkıştırarak Resul Tosun'un sözünü kesmesi de, bir başka içerik ve konu çarpıtma örneğidir. Elbette bir tartışma programı masasına gündemdeki diğer sıcak olaylar ve gelişmeler de getirilebilir, ancak bunu konuşmanın bağlamını hiçbir surette dikkate almayarak, ani bir konu geçişiyle sağlamaya çalışmak, meselenin izleyiciler tarafından sağlıklı biçimde algılanmasının önüne geçer ve asıl mevzuyu bütünlüklü olarak kavramayı güçleştirir. ${ }^{5}$ Burada, söz konusu müdahaleyi bizzat izlemeyi garanti etmenin sorumluluğunu üstlenmiş olan moderatörün yapması oldukça manidardır. Eğilmez, eristik diyalektik açıdan burada 'muhatabını kızdırma' yoluna başvurmuştur denebilir. Zira muhatabın öfke duymasını sağlayarak, onun doğru değerlendirme ve muhakeme yeteneğine ket vurulmuş olur (Schopenhauer, 2012a: 96). Özetle, yayın toplamda 2 saat 16 dakika 23 saniye sürmüş, bu sürenin 1 saat 23 dakika 5 saniyesi, konu başlığının tartışılmasına ve genel değerlendirmelere ayrılmış, programda 9 kez konu başlığı dışına çıkılmak suretiyle içerik çarpıtılmıştır. Yayının toplam net süresinin 23 dakika 56 saniyesini konu çarpitmaları oluşturmuştur. Programda, Berhan Şimşek-Resul Tosun polemiğinde, özellikle AK Parti-CHP politik karşıtlığına yoğunlaşıldığı görülmüştür ("Gerçek Fikri Ne?”, 02.10.2020).

Tablo 2: “Gerçek Fikri Ne?" Programının 2 Ekim 2020 Tarihli Yayınındaki Çarpıtma Unsurlarına Dair Detaylar

\begin{tabular}{|c|c|c|}
\hline $\begin{array}{c}\text { Çarpıtmanın Başlangıç ve Bitiş } \\
\text { Süresi }\end{array}$ & $\begin{array}{c}\text { Çarpıtmanın } \\
\text { Gözlendiği Toplam Süre }\end{array}$ & $\begin{array}{c}\text { Çarpıtmayı Yapan Konuşmacı veya } \\
\text { Konuşmacılar }\end{array}$ \\
\hline $23: 35-24: 35$ & 1 dakika & Berhan Şimşek \\
\hline $29: 32-29: 55$ & 23 saniye & Berhan Şimşek \\
\hline $44: 25-45: 35$ & 1 dakika 10 saniye & Cem Küesçük Tosun \\
\hline $49: 05-50: 00$ & 55 saniye & Sinan Oğan \\
\hline $1: 00: 05-1: 00: 30$ & 25 saniye & Sinan Oğan \\
\hline $1: 03: 56-1: 04: 35$ & 39 saniye & Bun \\
\hline
\end{tabular}

\footnotetext{
${ }^{5}$ Bu durum, tam da Pierre Bourdieu'nün ‘perdeleme işlevi' dediği şeydir. Bu da gayet anlaşılırdır; çünkü genel olarak medyanın ekonomi-politiği derinlikli biçimde bilgilenmeyi değil, izlemeyi gerektirir. Bu anlamda medyatik söylemin akıbeti, ekonomik pazar sisteminin eğlenceyi, parçalı yapıyı ve yüzeyselliği öne çıkaran güçlerinin mutlak nezareti altındadır. Daha ayrıntılı bilgi için bkz. Hüseyin Köse, Bourdieu Medyaya Karşı, Papirüs Yayınları, İstanbul, 2004, ss.24-30.
} 


\begin{tabular}{|c|c|c|}
\hline $1: 05: 08-1: 11: 20$ & 6 dakika 12 saniye & Berhan Şimşek, Cem Küçük, Resul Tosun \\
\hline $1: 12: 10-1: 23: 05$ & 12 dakika 55 saniye & Resul Tosun, Berhan Şimşek, Cem Küçük \\
\hline $1: 15: 43-1: 16: 00$ & 17 saniye & Eren Eğilmez \\
\hline
\end{tabular}

\section{C. “CNN Türk Masası” Programı}

CNN Türk TV kanalında Semiha Şahin'in moderatörlüğünü yaptığ 1 "CNN Türk Masası" simli programın 3 Ekim 2020 tarihli bölümü de Ermenistan-Karabağ Savaşı'nı konu etmesi açısından önemlidir. Programa İstanbul'dan Yenilik Partisi Genel Başkanı Öztürk Yılmaz, 26. Dönem AK Parti İstanbul Milletvekili Mehmet Metiner, gazeteciyazar Nedim Şener, kamuoyu araştırmacısı Hakan Bayrakçı ile; Ankara'dan gazeteci Metin Özkan katılmıştır. Yayın bölümünün başlı̆̆ "Dağlık Karabağ'a 300 Suriyeli Cihatçı Gitti mi? Büyük Savaş Kapıda mı?” şeklindedir. Yayının 8. dakikasında, AK Parti Eski Milletvekili Mehmet Metiner, cihatçıların Karabağ'da savaştıkları iddiasını dile getiren soruya yanıtının daha ilk cümlesine CHP'yi ve Cumhuriyet gazetesini hedefe koyarak başlar. Dahası, Metiner çeşitli imalarda bulunur ve Ünal Çeviköz örneğine gönderme yaparak, tüm iktidar muhaliflerini “içimizdeki Macron'lar" şeklinde tanımlar. Tartışmacı Metiner'in konuşması da 'bir olayın asıl nedeni olmayan şeyi o olayın gerçek nedeni gibi sunma' hilesi içerir. Bu ise, bariz bir çarpıtma örneğidir, çünkü Suriyeli cihatçılar meselesinin asıl nedeni CHP'nin kurumsal tavrı değildir. Öte yandan yine burada, tartı̧̧macının yetersiz bilgiyle muhatabını ikna etme çabası içinde olduğu bir durum vardır. Ne var ki, Aristo'nun da vurguladığı gibi, “ bilgiye dayalı kanıt öğrenim gerektirir" (2014: 36).

Aynı şekilde, yayının 74. dakikasında, Metin Özkan, Metiner'in tanımlamasına arka çıkarcasına "içimizdeki Kardaşyan'lar" ifadesini kullanır. Moderatörün araya girmesiyle, söz Hakan Bayrakçı'ya verilir ve Bayrakçı, hararetli, yüksek sesle ve hatta elindeki dosyayı masanın üzerine vurarak sert bir hamle yapar. Ardından, Metin Özkan da bu tartı̧̧maya dâhil olur ve her ne kadar "CHP'yi konuşmak istemediğini" belirtse de, her seferinde mutlaka konunun bu noktaya geldiğini serzenişlerle dile getirir. Ancak görülen odur ki, Özkan, tartışmanın bu şekilde seyretmesinden pek de rahatsızlık duyuyora benzememektedir, çünkü Özkan sert tirat atmak konusunda Bıçakçı'dan daha istekli görünür. Hatta bir ara, bu ve benzeri mesnetsiz iddialara karşı daha yüksek sesle tepki gösterilmesi gerektiğini bile savunur. Tartışma sırasında Hakan Bayrakçı, ara sıra muhalefet ve onun üyelerinin bazı söylemlerini doğru bulduğunu belirtir, ancak daha bunu der demez, stüdyodaki diğer konuklar tarafindan bu tutumundan dolayı sert biçimde kınanır. Öztürk Yılmaz da ilkin sakin bir şekilde konuşmaya başlar, ancak o da zaman zaman kendini dizginleyemez ve bir yerde savaş istemeyenlere "vatan haini" yakıştırması bile yapar. Ancak tam bu esnada, moderatör tarafindan biraz ironi dolu, "savaşa hayır diyenler vatan haini mi?" sorusu ile yüz yüze gelir. Yılmaz, bunun üzerine kendisine katkı sağlamak amacı ile destek verenleri bile kabul etmediğini haykırarak, kendisini retoriğin büyüsüne kaptırır. Yılmaz'ın ve diğer konuşmacıların tavrında açıkça 'tribünlere oynama' eğilimi görülür. Oysa söz konusu tavrın bir iddiayı savunmakta veya aksine, çürütmek konusunda hiçbir etkisi yoktur. 
TV Tartışma Programlarında Çarpıtma Unsurları: II. Karabağ Savașı (ErmenistanAzerbaycan Çatışması) Örneği

Verilen reklam arasının ardından, yayının yeniden aynı doğrultuda devam ettiği gözlenir. Tartışmanın 36. dakikasında, Mehmet Metiner'in Bayrakçı'ya yönelik politik eleştiriler yöneltmesi ve onu açıç̧a suçlaması, CHP Genel Başkanı Kemal Kılıçdaroğlu'nu eleştirmemesini bahane etmesi iki taraf arasında gerginliğe neden olur. Burada, açık biçimde her iki konuşmacı açısından da kendi 'muhatabını kızdırma' eğilimi söz konusudur. Konu, Dağlık Karabağ sorunu, II. Karabağ Savaşı, vd. güncel gelişmelerden çok uzaktır. Tartışmanın büyük kısmı daha ziyade hararetli biçimde CHP eleştirisine kilitlenir ve ekranda ansızın "Büyük Savaş Kapıda mı?” soru cümlesi belirir. Nitekim yayının 41. dakikasında, Öztürk Yılmaz, "Arkadaşlar, Karabağ'la, Azerbaycan'la ilgili konuşalım" şeklinde bir ikazda bulunmak zorunda kalır. Moderatör Semiha Şahin ise "Konuşacağız, konuşacağız, zamanımız var" minvalinden bir karşılık verir ona. Ardından, moderatör Nedim Şener'den de bir tutum sergilemesini ister. Şahin, ara sıra konunun dağıldığını dile getirse de, buna sebebiyet veren de bir anlamda yine kendisidir. Çünkü dağılan konuyu toparlamak için araya girmeyerek, konuşmacılara zaman zaman müdahale etmeyerek, ekrandaki reyting kokan "heyecanll" anlara göz yumarak, yukarıda sözünü ettiğimiz ekonomi-politik yasayı doğrular. Nitekim YouTube üzerinden gelen yorumlardan birinde de, moderatörün reyting için çatışmayı körüklediği, hatta Hakan Bayrakçı'ya, ithamlara cevap vermesi için gizli bir el hareketi ile davet işareti bile yaptığı vurgulanır. Mehmet Metiner'in tartışmayı Kuzey Kıbrıs Türk Cumhuriyeti Eski Cumhurbaşkanı Mustafa Akıncı'nın söz konusu savaşla ilgili net bir açıklama yapmamasına binaen onu "Rum zihniyetli" olarak adlandırması, diğer uzmanların da bu tartışmaya katılması için açık bir firsat sunmuş olur. Söz konusu benzetmenin, Schopenhauer'in formüle ettiği biçimiyle, "muhatabın önermesini, ondan yanlış bir çıkarımda bulunarak değersizleştirme" amacına hizmet ettiği söylenebilir (2021a: 103). Çünkü burada KKTC Eski Cumhurbaşkanı'nın 'Rum zihniyetli' olduğunun iddia edilmesi, 'Büyük Savaş Kapıda Mı?' tartışma başlığının önemini azaltma ve olası yanıtlarını değersizleştirme işlevi görür.

Hakan Bayrakçı da konuşma süresinin eşitsiz bir biçimde paylaşılması ve konuların dağılmasını eleştirir. Bayrakçı, kendi konuşmasında, retoriğin unsurlarından birisi olan hikâye anlatma metodunu kullanır ve konuşmasını mecazlar ve örneklerle pekiştirmeye çalışır. Bu ise ikna etme sanatının etkili bir uygulamasıdır. Nitekim eğer tartışma mecazı veya tasviri gerekli kılan bir fikir etrafında dönüyorsa, önerme için uygun bir mecaz veya örnekler seçilmesi gerekir (Schopenhauer, 2012a: 97). Ardından, Metin Özkan daha önceki program örneğinde değinildiği gibi, Abdullah Gül'ün Ermenistan ziyaretini, bu konuda kendisinin Devlet Bahçeli'nin tutumunu savunduğunu ve DP'nin Kuzey Kıbrıs ve Karabağ açıklamalarını dile getirir. Yayının 98. dakikasında, ekranda "Karabağ'da Büyük Savaş Kapıda mı?” başlığının da değiştirilmesi ile tartışmanın akışı FransaTürkiye çatışmaları, Fransa Cumhurbaşkanı Emmanuel Macron'un açıklamaları, HDP, Kobani Operasyonu gibi konulara evrilir. Toplam 3 saat 57 dakika 3 saniyelik yayının, belirlenen konu başlığıyla doğrudan ilgili 1 saat 38 dakika 36 saniyelik yekûnunun 1 saat 2 dakika 42 saniyelik kısmının çarpıtmalardan oluşması, çalışmanın iddialarını kanıtlar niteliktedir. Özellikle Mehmet Metiner'in, Karabağ'dan daha çok CHP ve hatta CHP'den de çok İYİ Parti'nin fikirlerine yakın olan Hakan Bayrakçı'nın bakış açısını tartışma konusu yapması, sürekli olarak ona sataşmalarının da altını çizmek gerekir. Çünkü 
haddizatında 'muhatabı kızdırmak' da bir tartışma hilesi ve çarpıtma unsurudur. Moderatörün de reyting ve gösteri için bu sapmalara izin vermesi, sonunda tartışmanın Hun İmparatorluğu'nun dış siyasetine kadar gitmesine firsat sunar ("CNN Türk Masası", 03.10.2020).

Tablo 3: "CNN Türk Masası" Programının 3 Ekim 2020 Tarihli Yayınındaki Çarpıtma Unsurlarına Dair Detaylar

\begin{tabular}{|c|c|c|}
\hline $\begin{array}{l}\text { Çarpıtmanın Başlangıç ve Bitiş } \\
\text { Süresi }\end{array}$ & $\begin{array}{c}\text { Çarpıtmanın } \\
\text { Gözlendiği Toplam Süre }\end{array}$ & $\begin{array}{l}\text { Çarpıtmayı Yapan Konuşmacı veya } \\
\text { Konuşmacılar }\end{array}$ \\
\hline $8: 21-8: 39$ & 18 saniye & Mehmet Metiner \\
\hline $12: 30-32: 40$ & 10 dakika 10 saniye & $\begin{array}{l}\text { Mehmet Metiner, Semiha Şahin, Hakan } \\
\text { Bayrakçı, Metin Özkan, Öztürk Yılmaz }\end{array}$ \\
\hline $33: 14-1: 13: 09$ & 29 dakika 55 saniye & $\begin{array}{c}\text { Öztürk Yılmaz, Mehmet Metiner, Hakan } \\
\text { Bayrakçı, Semiha Şahin, Metin Özkan, Nedim } \\
\text { Şener }\end{array}$ \\
\hline $1: 14: 12-1: 16: 56$ & 2 dakika 44 saniye & Metin Özkan \\
\hline $1: 18: 01-1: 38: 36$ & 20 dakika 35 saniye & $\begin{array}{c}\text { Metin Özkan, Mehmet Metiner, Öztürk } \\
\text { Yılmaz, Hakan Bayrakçı, Nedim Şener, Semiha } \\
\text { Şahin }\end{array}$ \\
\hline
\end{tabular}

D. “Tarafsız Bölge” Programı

CNN Türk TV'de yayımlanan "Tarafsız Bölge” isimli programın 19 Ekim 2020 tarihli “Ermenistan'ın Amacı ve Gizli Planı Ne? Ermenistan'a Kimler Silah Veriyor?" başlıklı yayınına İstanbul stüdyosundan Yeditepe Üniversitesi Öğretim Üyesi Prof. Dr. Mesut Hakkı Caşın, Star gazetesi yazarı Sevil Nuriyeva, kamuoyu araştırmacısı Hakan Bayrakçı ile Ankara'dan emekli hava pilot korgeneral Dr. Erdoğan Karakuş, Bakü’den Tovuz Milletvekili Ganire Paşayeva ve Azerbaycanlı sanatçı Azerin konuk olarak katılmışlardır. Yayının 48. dakikasında, İYİ Parti İstanbul Milletvekili Ümit Özdağ’ın, aynı partinin İstanbul İl Başkanı Buğra Kavuncu'nun FETÖ’cü olduğu iddiası üzerine güncel konudan uzaklaşılır ve başka bir tartışma açılır. Önceki çözümleme birimlerinden de anımsanacağı üzere, burada da tartışma programının asıl konusu II. Karabağ Savaşı değildir. Yayın konu başlığının bu şekilde dağılmasının nedeni, olmadık yerlerde sansasyonel nitelikli siyasal retoriğin araya sokularak yayının izlenirlik oranının yükseltilmeye çalışılmasıdır denebilir. Moderatör Ahmet Hakan, Özdağ'ın ithamları nedeniyle Kavuncu'ya cevap hakkı doğduğunu, tarafsızlık ve eşit söz hakkı adına izah etmek için araya girer. Ne ki, yayının genel akışı dikkate alındığında, moderatörün adil söz hakkı dağıtımı konusunda olumlu bir sınav verdiği söylenemez. Stüdyodaki kamuoyu araştırmacısı Hakan Bayrakçı'nın da kurduğu cümlelerle Ümit Özdağ-Buğra Kavuncu ihtilafının tartışılmasını destekleyerek, tümüyle tali nitelikli bir tartışmayı egemen kılmak suretiyle, politik retoriğin görünürlük kazanmasına cevaz verdiği söylenebilir. Konu başlığının tartışmacılar tarafından bu biçimde kasıtlı olarak değiştirilerek iç politik meselelere ve bu meselelerin bilinen taraflarına odaklanılması, 
TV Tartışma Programlarında Çarpıtma Unsurları: II. Karabağ Savașı (ErmenistanAzerbaycan Çatışması) Örneği

aslında dolaylı olarak "kendisini dinleyenleri karşıtlarına karşı öfkelendirecek şekilde konuşmak"la ilgilidir (Aristo, 2014: 23) ve bu da, 'muhatabını kızdırmak' biçiminde formüle edilen çarpitma unsurudur. Nitekim bu taktik işe yarar ve sonunda adı geçen Kavuncu yayına telefonla bağlanma ihtiyacı duyar.

Yayının 79. dakikasında açılan söz konusu tali konu başlığı zorlukla kapatılırken, Bayrakçı'nın, IYYI Parti'den gelen resmi bir açıklamayı stüdyoda okumaya kalkışması üzerine, Ahmet Hakan, bu konuda yeniden bir tartışma açılmasını istemediğini belirtir. Ancak gelgelelim, stüdyonun kontrolünü sağlayamaz ve müdahalesi yalnızca cılız bir itirazdan öteye geçemez. Böylelikle İYİ Parti'nin tartışılmasına devam edilir. Akabinde, zorlukla II. Karabağ Savaşı konusuna geri dönüldüğünde, Ahmet Hakan'ın yabanc1 ülkelerin liderlerinin bu sorun hakkında sergiledikleri suskun tavırlarıly ilgili sorusuna cevaben, Azerin'in Azerbaycanlı gençlerin konuyla ilgili sosyal medya tepkilerinden, enformasyon savaşından, vb. gelişmelerden söz etmesi, moderatörün sansürüne uğrar. Kendisine sunucu tarafından asıl mevzuunun bu olmadığı hatırlatılır. Burada Azerin'in tavrı 'rastlantısal olanı temel olarak alma' arzusuna dayanır (Schopenhauer, 2012a: 157) ve bu, bariz bir çarpıtma eğilimidir.

İzleyen dakikalarda, tekrar söz alan Hakan Bayrakçı, uluslararası kültür ve sanat dünyasında Türk düşmanlığı üzerine konuşmaya başlar. Hollywood filmlerinin, Martin Luther, Jean-Jacques Rousseau, vd. ünlü düşünürlerin Türklerle ilgili olumsuz algı ve fikirlerinden dem vurur. Ancak bu söylev moderatörü pek memnun etmez ve tüm bilgilerin asıl konuyla ne ilgisi olduğu sorulur kendisine. Burada, Bıçakçı'nın başvurduğu çarpitma unsuru “'vitrine oynamak' şeklinde izah edilebilir. Daha ilk cümlelerden itibaren Erdoğan Karakuş'un sözünü kesen Hakan, müdahalesine uygun bir bahane bulamadığı görülünce, çareyi sözü yeniden Karakuş’a vermekte bulur. Daha sonra Hakan Bayrakçı'nın, Victor Hugo'dan bir pasaj okumak istemesiyle, tartışma diyagonal biçimde yeniden açı değiştirir. Hugo'nun, “Türkler, Tanrı'nın öfkeli kırbacı, yakıp yıkan Şeytan'ın uşaklarıdır. Bir Türk'ü öldüren vicdan azabı duymamalıdır"' ifadesini aktaran Bayrakçı, moderatörün şaşkın bakışlarıyla karşı karşıya kalır. Dahası, Hakan; "Doğru mu söylenenler acaba?" diye mütereddit bir ruh hali içinde mırıldanır. Bıçakçı'nın iddialarını öne sürerken başvurduğu tarihsel örnekler dilsel çarpıtmanın 'herhangi bir zaman ya da koşuldan söz etmeme' unsuruna karşılık geldiği söylenebilir (Schopenhauer, 2012a: 157). Çünkü bazı düşünürlerin ağzından verdiği örneklerin tartışılan meselenin tarihsel gelişimiyle doğrudan veya dolaylı olarak hiçbir ilgisi yoktur. Koşullar ve zaman dilimleri tamamen faklıdır. İkinci olarak, Bayrakçı'nın verdiği örneklerle 'sonuçtan kanıt çıkarma' yoluna gittiği görülür ki, bu da başka tartışma hilelerinden birisidir (Schopenhauer, 2012a: 157).

Benzer şekilde, Bayrakçı, Voltaire'e de benzer bir atıf yapmak isteyince, bu kez Mesut Hakkı Caşın araya girip onu susturmaya çalışır. Yayının 93. dakikasında Ahmet Hakan, gazeteci Celal Eren Çelik'le telefon bağlantısı kurunca, konu başlığı yine değişir. Yaptığının, "stüdyoda bekleyen konuklara karşı da hiç etik bir davranış olmadığını" kabul eden, programda "zaten karma bir formatla ilerlediklerini" söyleyen moderatör, "bunun farkında olduğunu", "ancak yayıncılığın doğası gereği bu tür canlı telefon bağlantılarının yapılması gerektiğini” dile getirerek seyircilerden özür diler. Böylesi 
gelgitlerle dolu bir yayın akışı içinde, ortalama bir seyirci olarak asıl konuya odaklanabilmek oldukça zordur. Özellikle de dikkatin çok kit bir değer olduğu yeni medya çağında. Özetle, yayın toplamda 2 saat 31 dakika 45 saniye sürmüş, yayın esnasında türlü retorik hilelerle $7 \mathrm{kez}$ ve toplam 38 dakika 21 saniyelik bir süre boyunca asıl konudan sapılmıştır. Moderatör, çarpıtmalara çok da mahal vermek istemiyormuş gibi görünmekle birlikte, denebilir ki, çoğunlukla bizzat kendisinin konukların tartışma konusuyla doğrudan bağlantılı sözlerini "konudan uzaklaşıldı̆̆ı" gerekçesiyle yorumladığı bölümler vardır. Moderatörün bu şekilde konuşmanın içeriğine doğrudan müdahale etmesi de, kuşkusuz bir başka çarpıtma türü olarak değerlendirilebilir ("Tarafsız Bölge", 19.10. 2020).

Tablo 4: "Tarafsız Bölge" Programının 19 Ekim 2020 Tarihli Yayınındaki Çarpıtma Unsurlarına Dair Detaylar

\begin{tabular}{|c|c|c|}
\hline $\begin{array}{l}\text { Çarpıtmanın Başlangıç ve Bitiş } \\
\text { Süresi }\end{array}$ & $\begin{array}{l}\text { Çarpitmanın Gözlendiği } \\
\text { Toplam Süre }\end{array}$ & $\begin{array}{l}\text { Çarpıtmayı Yapan Konuşmacı veya } \\
\text { Konuşmacılar }\end{array}$ \\
\hline $48: 20-1: 12: 05$ & 23 dakika 45 saniye & Ahmet Hakan, Hakan Bayrakçı \\
\hline $1: 16: 47-1: 17: 58$ & 1 dakika 11 saniye & Azerin \\
\hline $1: 22: 07-1: 25: 32$ & 3 dakika 25 saniye & $\begin{array}{c}\text { Hakan Bayrakçı, Mesut Hakkı Caşın, } \\
\text { Sevil Nuriyeva }\end{array}$ \\
\hline $1: 25: 34-1: 26: 04$ & 30 saniye & Ahmet Hakan \\
\hline $1: 31: 36-1: 32: 45$ & 1 dakika 9 saniye & Hakan Bayrakçı \\
\hline $1: 32: 49-1: 33: 20$ & 31 saniye & Ahmet Hakan \\
\hline $1: 33: 43-1: 41: 33$ & 7 dakika 50 saniye & Ahmet Hakan \\
\hline
\end{tabular}

\section{Sonuç}

Retoriğin, ister Homeros'tan tevarüs etmiş olan metinler ve Aristoteles'in klasik Retorik adlı eseri olsun, isterse medya metinlerinde başvurulan retorik çözümleme yöntemleri açısından sosyal teori içinde her dönemde güncelliğini koruduğu söylenebilir. Eski Çin ve Hint felsefesinden Antik Yunan'a, Sofistler'den Orta Çağ'a, Aydınlanma Dönemi'nden XXI. yüzyıla kadar retorik, zaman zaman form değiştirmiş, farklı yönlerden ele alınmış ve başka amaçlarla kullanılmış olsa da, etkileri ve işlevleri günümüze dek çok az değişime uğramıştır. Bu bağlamda, retorik, temelindeki ikna edici işlevini hiçbir zaman yitirmemiş, hakikate yahut inanılması mümkün olana hizmet edip etmemesine bakılmaksızın, daima içeriğinde bir inandırma, yönlendirme, etkileme ve bazen de saptırma işlevlerini barındırmıștır. Medya dünyasının -Douglas Kellner'ın Medya Gösterisi (2010) adlı kitabında izini sürdüğ̈̈ biçimiyle, 'medya gösterisi’nin- bir parçası olan tartı̧̧ma programları da bunun en çarpıcı kanıtı niteliğindedir. Olgusal gerçeklikler, medya retoriğinde ve özel olarak da TV tartışma programlarında konu başlıkları, moderatörlerin tavırları, televizyon kuruluşlarının kendi yayın politikaları, 
TV Tartışma Programlarında Çarpıtma Unsurları: II. Karabağ Savașı (ErmenistanAzerbaycan Çatışması) Örneği

davet edilen konuşmacı ve tartışmacıların farklı bakış açıları ve ideolojik tutumları içinde genellikle kırılmaya uğrar. Böylece, TV tartışma programları her açıdan toplumsal gerçekliğin gösterisine sahne olur.

Çalışmada incelenen 4 tartışma programı örneği kapsamında; toplam yayın süreleri, güncel soruna ayırdıkları zaman, çarpıtma unsurunun kaç kez ve ne kadar süre boyunca görüldüğüne ve özellikle hangi zaman aralıklarında kaydedildiğine dair nicel anlamda toplam 14 çözümleme kategorisi üzerinden içerik analizi yapılmıştır. Detaylar ve çarpıtmanın failleri, her yayın çözümlemesinin sonunda tablolarda gösterilmiştir. 4 yayın dikkate alındığında, en az çarpıtma süresinin 23 dakika 56 saniye; en fazla çarpıtma süresinin ise, 1 saat 2 dakika 42 saniye olduğu tespit edilmiştir. Çarpıtmaların en az olduğu program örneği Eren Eğilmez'in moderatörlüğündeki Gerçek Fikri Ne?; en fazla çarpitmaya rastlanan program ise, Semiha Şahin'in moderatörlüğünde yayımlanan $C N N$ Türk Masası'dır. Çalışmada, gerek uzmanların genel konuşmaları, gerekse çarpıtma unsuru barındıran söylemlerine ilişkin retorik bir analiz gerçekleştirilmiştir. Söz konusu çözümleme sonucunda tespit edilen genel bulguları şu şekilde özetlemek mümkündür:

Moderatörler. Tartışma programlarının esas yüzü olan moderatörler, yönetimini üstlendikleri programların yayın politikasını temsil etmekte, aynı zamanda bütün yayın sürecini belirleyebilmektedirler. Çözümlemelerde tespit edilen toplam çarpıtma sürelerinde moderatörlerin tavırları, yorumları, tutumları, araya girip söz kesmeleri, konu başlığı açma, değiştirme ve kapatma, konuklara söz hakkı dağıtımı gibi unsurlar çok önemlidir. Bu anlamda, en fazla çarpıtmanın gözlendiği CNN Türk Masası programının moderatörlüğünü üstlenen Semiha Şahin'in -program bölümlerine gelen izleyici yorumlarından hareketle söylenirse- reyting odaklı yayıncılığa öncelik verdiği ve kasten konuyu sansasyonel yönde değiştirdiği görülmüştür. Diğer program moderatörleri olan Kübra Par, Eren Eğilmez ve Ahmet Hakan'ın yönettikleri yayınlarda da birçok çarpıtma unsuru kaydedilmiş olmakla birlikte, buradaki çarpıtma nedenlerinin moderatörden çok uzman konuşmacılardan kaynaklandığı söylenebilir. Elbette, her üçünün de söz konusu çarpıtma hamlelerini bireysel nedenlerin yanı sıra, görev yaptıkları TV kanallarının yayın politikaları doğrultusunda gerçekleştikleri de aşikârdır.

Uzmanlar. Program davetlisi olan aydın, kanaat önderi veya uzmanların, televizyonun etki gücüne göre hesaplanmış kişiler olarak seçildiklerine şüphe yoktur. Çalışmada çözümlenen yayın örneklerinin birçoğunda, hep aynı kişilerin uzman olarak yayına davet edilmesi ve çoğunlukla karşıt görüşlü ve gerginlik/taşkınlık çıkarmaya dolayısıyla yayını eğlenceli kılıp izletmeye- yatkın uzmanların karşı karşıya getirtilmesi de reytinge göre düşünülmüş bir diğer mizansendir.

Özetle medya, her ne kadar olgusal gerçekliğe bağlı kaldığını, gerçekleri gün yüzüne çıkarmaya ve kamuoyuna takdim etmeye çalıştığını iddia etse de, genel olarak liberal çoğulcu medya düzeninin ve özel olarak da televizyonun işleyiş yapısı büyük ölçüde reklam gelirleri ve izleyici oranları gibi kantitatif verilerin ışığında şekillenmektedir. Televizyon tartışma programları gibi editöryal nitelikli (bilgilendirici) yayın içerikleri de bu kuraldan muaf değildir. İzleyiciyi heyecanlandırmak, oyalayıp eğlendirmek, ekrana kilitlemek ve çoğunlukla başka türden bilgilenme yollarını manipüle etmek gibi işlevlere sahiptir. İdeal olarak ise, medya kuruluşlarının kamunun gelişmeler hakkında doğru 
bilgilenme hakkını ve genel kamu yararını gözetmek gibi toplumsal yükümlülükleri vardır. $\mathrm{Bu}$ sebepten, olgusal gerçekliği olmadık bir biçime çarpitarak bilinçleri yönlendirmek ve kamuoyunu yanıltmaya çalışmak telafisi imkânsız birçok etik ihlal alanı oluşturur. Oysa temel mantığı, ilkesi ve asıl varlık nedeni doğruyu söylemek olan yayın kuruluşları ve özelde televizyon gazetecileri, söz konusu çarpıtmaları en aza indirecek şekilde davranıp her tür manipülasyon ve yanıltıcı söz edimiyle mücadele etmeli, özgül grup çıkarlarına değil, toplumsal dünyanın nesnel gerçekliğine bağlı kalmayı yerleşik bir norm haline getirmek zorundadırlar.

\section{Kaynaklar}

Aristoteles (2014). Retorik. (Çev.: Mehmet H. Doğan). Yapı Kredi Yayınları.

Azerbaycan-Ermenistan Gerilimi: Türk Ordusu İ̧̧in Yeni Bir Cephe Mi? (28.09.2020). www.youtube.com.

Berens, E. M. (2009). The myths and legends of Ancient Greece and Rome. MetaLibri. 23.09.2021 tarihinde https://www.ibiblio.org/ml//ibri/b/BerensEM_MythsLegends_p.pdf adresinden edinilmiştir.

Berger, A. A. (1998). Media research techniques. Thousand Oaks, CA: Sage Publications.

Bıçakçı, A. B. (2012). "İkna Edici İletişim ve Retorik Analiz.” Ö. Güllüoğlu (Ed.), Illetişim Bilimlerinde Araştırma Yöntemleri. Yazılı Metin Çözümlemeleri (ss.334-361) içinde. Ütopya Yayınevi.

Coşkun, A. (2014). İbn Sina Felsefesinde Retorik. Litera Yayıncılık.

Çarpıtma. (30.08.2021). https://sozluk.gov.tr.

Dağlık Karabağ’a 300 Suriyeli Cihatçı Gitti Mi? Büyük Savaş Kapıda Mı? (03.10.2020). www.youtube.com.tr.

Duman, M. A. (2015). Platon'un Retorik Anlayışı. Litera Yayıncılık.

Dürüşken, Ç. (2001). Antik Çağ'da Doğan Bir Eğitim Sistemi: Rhetorica. Roma'da Rhetorica Eğitimi. Arkeoloji ve Sanat Yayınları.

Emekli Büyükelçi ve CHP Genel Başkan Yardımcısı Çeviköz: Türkiye'den Azerbaycan'a Silah Yardımı Yapıldĭğ Ifade Ediliyor. (28.09.2020). https://tr.sputniknews.com.

Ermenistan Geri Adım Atacak Mı? (02.10.2020). https://tv.haberturk.com.

Ermenistan Gül'ü Bekliyor. (10.09.2020). www.cumhuriyet.com.tr.

Ermenistan'ın Amacı ve Gizli Planı Ne? Ermenistan'a Kimler Silah Veriyor? (19.10.2020). www.youtube.com.

Ertuna, C. (2018). “Türkiye'de Televizyonlarda Kanaat Üretimi: Haber Kanallarındaki Tartışma Programları ve Kanaat Teknisyenleri." Galatasaray Üniversitesi İleti-ş-im Dergisi, 29, 57-82. 
TV Tartışma Programlarında Çarpıtma Unsurları: II. Karabağ Savașı (ErmenistanAzerbaycan Çatışması) Örneği

Gökçe, G. (1997). Televizyon Program Yapımcılı̆̆ı ve Yönetmenliği. Der Yayınları.

Gürer, M. (2014). Tartışma Kültürü ve Tartışma Programları. Volga Yayıncılık.

Kaya, A. R. (2016). İktidar Yumă̆ı: Medya, Sermaye, Devlet. Ankara: İmge Kitabevi.

Köse, H. (2004). Bourdieu Medyaya Karşı. Papirüs Yayınları.

Kellner, D. (2010). Medya Gösterisi. (Çev.: Zeynep S. Doğruer). Açılım Kitap.

Leach, J. (2000). "Rhetorical analysis." Qualitative researching with text, image and sound içinde (ss. 207-226). Editions Sage Publications.

Məmmədli, Z. (2012). TV Proqramlarının Hazırlanması. Bakı: ATӘT Bakı Ofisi.

Moran, Y. (1992). Eşanlamlı Sözcükler ve Karşıt Anlamları Sözlüğü. Spatyom Yayınları.

Murphy, J. J. \& Katula, A. R. (2003). A synoptic history of classical rhetoric. Lawrence Erlbaum Associates, Incorporated.

Mutlu, E. (1995). Televizyonda Program Yapımı. Ankara Üniversitesi İletişim Fakültesi Yayınları.

Dezenformasyon Nedir? Sosyal Medya, Savaş Meydanı Oldu. (17.07.2020). https://journo.com.tr.

Sever, N. S. (2015). "Retorik Analiz ve Reklamlarda Kullanımı.” B. Yıldırım (Ed.), İletişim Araştırmalarında Yöntemler (ss. 321-337) içinde. Literatürk Academia.

Schopenhauer, A. (2012a). Tartışma Sanatının Incelikleri. (Çev.: A. Aydoğan). Say Yayınları

Schopenhauer, A. (2012b). Eristik Diyalektik (Haklı Çıkma Sanatı). (Çev.: Ü. Hıncal). Sel Yayınları.

Tepebaşılı, F. (2016). Retorik. Konuşma Sanatı- Söz Bilimi. Çizgi Kitabevi.

Yeniçă̆ Gazetesi Herkesin Unuttuğu Abdullah Gül, Ahmet Davutoğlu Detayın Hattrlatt. (30.09.2020). www.yenicaggazetesi.com.tr. 